\title{
Anmeldelser
}

Nordslesvigske præstearklver. I Torninglen Provstl.

Foreløbige arkivregistranter, udgivet af Landsarkivet for de sønderjyske Landsdele. Ảbenrå 1974, 102 sider, (stencileret).

Da Rigsarkivet i 1944 i serien Vejledende Arkivregistraturer udsendte bogen: Landsarkivet for de sønderjyske Landsdele, en Oversigt, ved Frode Gribsvad og Johan Hvidtfeldt, var det på en måde et pionerarbejde. Det var den første oversigt over det samlede indhold $i$ et dansk landsarkiv. Der var påtæenkt fortsættelser, omfattende de andre landsarkiver, indtil nu dxkkende Fyn og Sjxlland. Udgiverarbejdet gik for det sønderjyske arkivs vedkommende helt $\mathrm{i}$ stå. De andre landsarkiver har derimod udsendt en lang rakke arkivregistraturer, hvor navnlig Landsarkivet for Sjælland og Landsarkivet for Nørrejylland har været flittige.

$\mathrm{Nu}$ foreligger der imidlertid atter et arbejde fra Åbenrå, idet landsarkivet har udsendt et forste bind $i$ en påtænkt række af foreløbige arkivregistranter, der $\mathrm{i}$ første omgang skal omfatte de nordslesvigske præstearkiver, og forste bind registrerer Tørninglen provsti. Landsarkivar Peter Kr. Iversen skriver i forordet, at de sønderjyske præstearkiver på et par punkter adskiller sig fra de kongerigske. Vxsentligst er det vel nok, at de foruden kirkebøgerne indeholder et meget værdifuldt og omfattende materiale, som of te rækker tilbage til 1500-årene og $\mathrm{i}$ enkelte tilfxlde til middelalderen. De rummer ikke blot regnskaber, men også korrespondancer vedrørende sognenes kirkelige forhold, skole- og fattigvæsen, ligesom der of te findes sager af interesse for landbrugshistorikeren. Dette er baggrunden for, at der til forskel fra de kongerigske landsarkiver mangfoldiggøres fuldstændige registranter over de nordslesvigske præstearkiver.

Registreringen er gennemfort over en lang årrække, og de fleste af landsarkivets arkivarer har medvirket, hvorfor der er iøjnefaldende inkonsekvenser ved registreringen, skriver Peter Kr. Iversen, men inddelingen $\mathrm{i}$ hovedgrupper efter et opstillet hovedskema er ens. Der er for det sønderjyske områdes vedkommende den store forskel, at en række sogne, nemlig enklaverne, Tørninglen provsti og Als hørte under kongerigsk kirkelovgivning, medens det øvrige Sonderjylland hørte under Slesvig-bispen og dermed under de slesvigske kirkelove, 
hvorfor der ikke alene $\mathrm{i}$ kirkebøgernes førelse, men også med hensyn til ordning og opbevaring af præstearkiverne rådede forskellige principper.

Den foreliggende registrant, der forhåbentlig snarest efterfølges af en lang række andre ikke alene fra det kirkelige område, men også fra andre forvaltningsgrene, må hilses med stor tilfredshed af alle, der dyrker sønderjysk historie, enten det nu er de mange personaleller lokalhistorikere, eller det er dyrkere af andre felter inden for historieforskningen. Vel var registranten tilgængelig på landsarkivets læsesal, men nu kan den interesserede bruge registranten hjemme, på et bibliotek eller på et lokalhistorisk arkiv, idet det turde være en selvfølge, at bogen anskaffes af de nævnte sønderjyske institutioner og helst også af alle større biblioteker og arkiver i det øvrige land.

Der er grund til at være taknemlig over, at der nu udsendes sønderjyske registranter, og at onske arkivet og dets medarbejdere til lykke med dette første bind.

\section{Olav Cbristensen}

Ernst Joachim Fürsen: Der Hardesvogt Im Herzogtum Schleswig.

Kiel 1973, 126 sider +85 sider bilag.

Bogen, som har givet forfatteren den tyske juridiske doktorgrad, har et velvalgt emne. En nærmere undersøgelse af herredsfogdernes stilling i Sønderjylland kan nok have interesse på grund af den særlige udvikling syd for Kongeåen, bl. a. ved amtmændenes overtagelse af en stor del af retsplejen på bekostning af herredstingene. Det kan også være nyttigt at forklare tyske fagfolk noget om dette specielt danske begreb. Til gengæld er det ikke noget let emne at arbejde sig ind $\mathrm{i}$ for en tysker, der som Fürsen er født i Stettin og hovedsagelig uddannet syd for Ejderen. En vis tilknytning til Sønderjylland har han dog ved sin skolegang $i$ Rendsborg; og måske er han $i$ familie med 2 herredsfogder Fürsen, der i sin tid sad på Als og i Slogs herred. Han har lxst mange bøger med tilknytning til emnet, også en del danske, og har besøgt landsarkiverne i Slesvig og Abenrå samt Rigsarkivet $\mathrm{i}$ Kobenhavn.

Bogen er dog ikke helt tilfredsstillende. At selve disputatsen kun fylder 126 sider foruden 85 sider bilag og registre, skal i og for sig ikke bebrejdes forfatteren. Visse misforståelser som, at 1 tønde hartkorn sattes lig 1 tønde land, og af begreberne "dannemænd " og "birk « bør heller ikke tages for tungt; der kan også mange danske dumpe i. Fürsen fortæller en hel del - og overvejende korrekt - om de sønderjyske herredsfogders forhold og arbejde, især for tiden efter 1721. Men man kunne onske, at han nogle steder havde sat spaden dybere $i$ jorden, og især at arbejdet havde været mere færdigt og afrundet. 
Man savner til sammenligning med udviklingen ved herredstingene en kort oplysning om retsplejen i byerne, herunder særlig om byfogdens stilling. Et sted mener Fürsen, at Slesvig efter 1721 oplevede en lang tid med en godt funktionerende forvaltning. Det gælder dog vist kun, hvis man ser på forholdene med embedsmændsøjne; for lægfolk så det anderledes ud. Fürsen fremhæver selv et andet sted med rette, at »de tildels vanskelige og uforståelige love og procesmåder « $\mathrm{i}$ tidens løb gav den studerede herredsfoged overtaget over de egentlige dommere (sandemænd og nævninger), så han til slut optrådte som en slags formynder for dem. Det oplyses, at den første studerede herredsfoged ansattes $\mathrm{i}$ Vis herred 1656, mens Treja herred havde ustuderede fogder lige til 1824. Fürsen citerer også en interessant indberetning af 1771 fra amtmanden i Flensborg amt, der fandt en ulard herredsfoged med erfaring og nøje kendskab til almindelige forhold på landet langt nyttigere for befolkningen end en lærd, der savner disse egenskaber.

En klar fejl er det, at kejser Karl V's Halsgerichtsordnung skulle være indført i Slesvig allerede 1610; den såkaldte Carolina vandt først overhånd i straffesager ved de slesvigske herredsting efter 1720 . Det er også galt, at Fürsen regner med en vid brug af romerret i Sønderjylland. Om disse emner kan henvises til min bog fra 1968 »Tysk Strafferets Indtrængen i Sønderjylland « bl. a. s. 25 og 47.

Til slut oplyses, at herredsfogdens funktion som dommer i Sønderjylland afskaffedes 1867 , men at navnet herredsfoged endnu brugtes om underøvrigheden på landet til 1888, da der indrettedes prøjsiske amtsdistrikter (omfattende et eller to kirkesogne), hvert med sin "Amtsvorsteher «. Nord for Kongeåen forsvandt herredsfogderne med deres dobbeltstilling som dommer og politimyndighed forst 1919.

Af bogens bilag vil jeg nævne et enkelt, en hertugelig bestalling af 1675 for Detlef Ohem, der afløste faderen Hans Ohem som herredsfoged i Hohn herred. Det var en af de storbondeslxgter, som beholdt herredsfogedstillingen gennem mange slægtled. Den forste var Marquard Ohem, der havde reddet Christian I's liv og som løn herfor fik Hohngård og blev herredsfoged i 1480 . Denne værdighed bevarede familien med korte afbrydelser lige til 1713, og den sidder stadig på Hohngård; for nogle år siden overtog Detlef Ohem den efter faderen Hans Ohem, en af danskhedens bedste stotter i Ejderlandet.

Alt $i$ alt en bog med en hel del gode oplysninger om sit emne. Men den er ikke god nok til at kunne have givet en doktorgrad i Danmark; hos os er kravene til en juridisk doktorafhandling betydeligt strengere end i Tyskland. Man kunne ønske, at Fürsen eller en anden vil tage sig tid til en virkelig gennemarbejdning af emnet.

Frants Thygesen 
Marlen Sönnichsen und Ernst Sibbert: Vom Nordschleswigschen Brandversicherungsverein für bewegliche Habe Hadersleben 1847 zum Schleswiger Feuerversicherungsverein a.G. für Gebäude und bewegliche Habe Emmelsbüll 1972.

Flensborg 1972, 142 sider + 52 sider bilag, ill.

Den unge historiker Marlen Sönnichsen er forfatter til teksten, medens forretningsfører Ernst Sibbert har bidraget med statistikker og de faglige beretninger. Fremstillingen tager sit udgangspunkt i den klassiske oldtid, men hurtigt når man frem til de holstenske brandgilder i første halvdel af 1500-årene. En almindelig slesvig-holstensk brandforsikringsforening for landdistrikterne oprettedes 1758 , og fra slutningen af århundredet kendes også lokalt afgrænsede gensidige brandforsikringsforeninger. Den første landsdelsdxkkende forening for inventar oprettedes 1847 i Kolsnap under navnet Brandassurance-Foreningen for rørlige Ejendele i Nordslesvig. Trods navnet kunne alle i Mellem- og Sydslesvig også blive medlem, når blot et medlem ville kautionere for kontingentets betaling. Foreningen var oprettet i det danske Nordslesvig, og blandt dens ledere træffes derfor også navne, der er kendt fra den nationale kamp. Der gives iøvrigt en sympatisk skildring af danskhedens stilling under fremmedherredømmet, og der gengives bl. a. anekdoter om møller Wielandts landsfarlige danske vejrhane og om hans respektløse placering af en flagstang med det tyske flag på dyrskuepladsen i Gram. Skildringen viser en for en tysk historiker sjzlden forståelse for og indleven $i$ danskhedens vilkăr $\mathrm{i}$ disse årtier. Når dette er sagt, må det også være tilladt at bemærke, at de s. 37 omtalte preussiske velsignelser i økonomisk henseende for Nordslesvig måske nok tør karakteriseres som noget overdrevne. I denne periode sker den store afvandring fra landsdelen til stor skade for udviklingen, og når der tales om den storslåede hedeopdyrkning i de slesvigske geestegne, er denne jo dog kun en svag afglans af det danske hedeselskabs kultiveringsarbejder i Nørrejylland. I forbifarten kan det endvidere noteres, at afstemningen i 1. zone ikke var den 20., men den 10. februar 1920.

Ved genforeningen var der ca. 4000 medlemmer $\mathrm{i}$ foreningen syd for grænsen med en forsikringsmasse på 45 mill. mark, men inden der berettes om, hvad der skete med disse medlemmer, folger et kapitel om Lø Herreds Brandforsikringsforening for Landbygninger i Nordslesvig. Denne forening havde næsten den samme medlemskreds som forsikringsforeningen for de rørlige ejendele, og efter grænsedragningen danner medlemmerne af de to foreninger syd for grænsen en ny forening omfattende både bygninger og inventar under navnet Schleswigsche Feuerversicherungsverein auf Gegenseitigkeit für Gebäude und bewegliche Habe. Også de syd for grænsen boende medlemmer af Øster Terp Johannes gilde sluttede sig til den nye forening, som 
fik sit første sæde i Lille Vi og dernæst fra 1925-45 i Skovlund med Theodor Clausen som forretningsforer. Foreningens sæde flyttes 1945 til Emmelsbøl, og Ernst Sibbert, bogens medforfatter, overtager hvervet som forretningsfører. Især var àrene indtil 1932 på grund af store brandskader vanskelige, og der forhandles en overgang om indlemmelse i den slesvig-holstenske landsbrandkasse, men medlemmerne afviste denne sammenslutning. Efter valutareformen 1948 gik det på ny fremad for foreningen; nye forsikringsområder som storm-, tyveri-, vand-, stormflods- og automobilskader toges med, og endvidere indlemmedes brandforsikringsforeningerne for de seks syd-oktrojerede koge (1949) og for Kropp herred og Svansen (1968), således at foreningen $i$ dag takket være en dygtig og fremsynet ledelse næsten dækker hele det sydslesvigske område. I bogen, der er trykt på glittet kunsttrykpapir, er gengivet mange aktstykker, og der er mange billeder såvel af personer som af lokaliteter og ulykker. Bogen er af betydelig interesse for dem, der interesserer sig for brandforsikringsvæsenets udvikling $\mathrm{i}$ landsdelen.

Peter Kr. Iversen

Valdemar Andersen: Foldingbro. Administration, bygningshistorie, toldkontrol. Udg. af Historisk Samfund for Ribe Amt 1973, 169 sider, ill.

Som det vigtigste overfartssted over Kongeåen indtager Foldingbro en central placering i det sydlige Jyllands kulturhistorie, og det er en indlysende god idé af lokalhistorikeren Valdemar Andersen at benytte broen som udgangspunkt for sin nyeste bog. Det kan ikke undre os, for det er ikke første gang, at han beskxf tiger sig med centrale og interessante emner.

Broen over Kongeåen spiller naturligvis hovedrollen $\mathrm{i}$ bogen, men på grund af måden, emnet behandles på, er der ikke tale om en "brohistorie $\mathrm{i}$ snæver forstand, men snarere om et lokalhistorisk værk. Ganske vist fortælles broens bygningshistorie $\mathrm{i}$ alle detaljer, men det er nok så meget livet ved broen og $\mathrm{i}$ egnen omkring stedet, der gor sig gxldende. Dette er naturligt nok særligt fremtrædende $i$ afsnittene om toldkontrol, grænseregulering efter 1864, soldater, kro, bydannelse og markedsplads, men også i kapitlerne om selve broen oser forfatteren af sin omfattende viden om væsentlige og mindre vxsentlige begivenheder og betydningsfulde og mindre betydningsfulde personer. Lxseren får at føle, at der er drevet grundige arkivstudier.

Foldingbro var, indtil den moderne bro blev bygget i 1961, en træbro. Det kan måske undre, at en bro af mere varige materialer ikke blev opført før, og en undersøgelse i 1957 viste da også klart, at 
den gamle træbro slet ikke kunne honorere nutidens krav. En lastbil på 12 tons udsatte således broen for en overbelastning på $60 \%$. Derimod er der ikke noget mærkeligt $i$, at broen ikke blev bygget af sten allerede i slutningen af 1700-tallet eller begyndelsen af $1800-$ tallet, hvor så mange trabroer blev erstattet med kampestensbroer, for $\mathrm{i}$ vor del af Europa veg man tilbage for at bygge så lange broer at sten. Hovedårsagen var okonomisk, og mange smukke broprojekter rundt om $\mathrm{i}$ landet blev $\mathrm{i}$ de år henlagt af mangel på penge. Foldingbro var virkelig en lang bro $\mathrm{i}$ de dage, flere gange længere end $\mathrm{i}$ dag. Vald. Andersen afstår med rette fra at benytte den gradvise indskrænkning af broens længde som et mål for åens bredde (s. 47). Sådanne afkortninger er et almindeligt trak og skyldes ganske simpelt, at jordværkerne ved opkørslerne udbyggedes.

Der er stadig ikke mange danske broer, der har fået deres historie skrevet, og da de ikke alene har samfærdselshistorisk betydning, men også er af stor lokalhistorisk interesse, er det glædeligt, at endnu en vigtig bro er blevet behandlet. Aldrig for er der her $i$ landet blevet of ret så mange sider på en enkelt bros historie, og den gode plads har muliggjort en bred skildring af, hvad der foregik ved et sådant overfartssted. Mange forhold er specielle for Foldingbro, men andre er generelle.

Bogen er tilfredsstillende illustreret og er forsynet med kildefortegnelse, noter og registre.

Viggo Petersen

\section{Andreas Moller: Báde og bådfolk I marsken.}

Fiskeri- og sofartsmuseet i Esbjerg. Esbjerg 1973. 148 sider, ill., kort.

Denne bog er resultatet af nogle undersøgelser, som Fiskeri- og Søfartsmuseet i Esbjerg i 1968-71 foretog i marskegnene omkring den vestlige del af den dansk-tyske grænse. Som bogens titel angiver, er det især de forskellige typer af marskbåde, den beskæf tiger sig med, men $\mathrm{i}$ forbindelse hermed kommer undersøgelserne ganske naturligt ind på at klargøre bådens rolle for erhvervsforholdene $\mathrm{i}$ dette område.

Det må hilses med glæde, at vi her har fået en indgående og særdeles interessant behandling af de skiftende erhvervsforhold i netop disse egne, der i flere henseender - såvel gennem de ganske særprægede naturforhold, som de vilkår, som dette miljø har skabt for menneskets virksomhed - indtager en særstilling blandt de danske landskaber. Mere end noget andet sted $i$ vort land stilles vi her overfor den kendsgerning, at de fleste af de geografiske forhold, som mennesket lever under, er undergivet forandringer. Den landskabelige ud- 
vikling, som den pågældende egn har gennemgået, karakteriseres kort på følgende måde: "Mens diger i dag brat sæetter skel mellem land og hav, lå den middelalderlige Tøndermarsk som et fliget grænseområde, skiftevis behersket af $\stackrel{\mathrm{a}}{-}$ og tidevand . . Denne korte og rammende beskrivelse giver et tydeligt indtryk af, hvorledes de eksistensmuligheder, som disse egne har budt mennesket, har gennemgået store xndringer $\mathrm{i}$ tidens løb.

Den hyppige indtrængen af tidevandet gjorde det længe umuligt at skabe en fast beboelse $i$ marsklandet, og efter at der ved digebygningen var sat stopper for tidevandet, skete det jevnligt, at det ferske vand bredte sig ud over de lave enge, når sluserne ved stormvejr måtte holdes lukkede, således at Vidåens vand var spærret inde bag digerne. Men de storslåede afvandingsarbejder, der afsluttedes i begyndelsen af 1930'erne, betød ikke alene, at århundreders oversvømmelser blev bragt til ophør; men ved udtørringen af søer og moser m.v. blev landskabets karakter fuldstændig ændret, og dette bevirkede igen, at det nu var slut med marskboernes traditionelle nxringsveje. Fiskeriet ophørte delvis, og tagrørsbevoksningerne forsvandt. Befolkningens bxrende erhverv blev nu, da afvandingen havde muliggjort en bedre udnyttelse af jordene, i særlig grad landbruget.

Det er imidlertid næsten udelukkende tiden før afvandingen, som bogen beskxftiger sig med. Under de forhold, der var herskende dengang, var båden det eneste transportmiddel i størstedelen af marskområdet. Den var simpelthen en forudsæetning for de fleste marskboeres tilværelse. Men dette, at marskområdet ikke alene var gennemfuret af større eller mindre kanaler, men at der også var åer og større vandsamlinger som Gudskog sø, Aventoft sø og Rudbøl sø, samt den omstændighed, at bådene foruden at skulle anvendes til forskellige former for transport også var nødvendige ved fiskeri og jagt, betød, at der måtte være forskellige typer af marskbåde - alt efter hvad de skulle bruges til. Bogen giver en meget detailleret beskrivelse af de forskellige marskbådes konstruktion, og denne beskrivelse illustreres på en udmærket måde af en lang række opmålingstegninger og andre tegniger. Men et endnu mere levende indtryk af de forskellige marskbåde får man gennem det meget store antal fotografier, som viser bådene i de forskellige funktioner, som de havde.

Et fælles træk for marskbådene var den flade bund og det ringe dybgående. De blev staget frem - roning anvendtes ikke. De fleste af bådtyperne kunne fore et sejl, men de smalle vandvejes specielle karakter, og den høje rørbevoksning, der fandtes mange steder langs kanalbredderne, forhindrede of te udnyttelsen af vinden.

Bådene anvendtes til transport af $f$. eks. hø, korn, kul, koks og andre nødvendighedsartikler, og desuden blev kreaturerne fragtet pr. båd til og fra Tønder til græsning i Gudskog. Men bådene dannede 
også grundlaget for den vigtige udnyttelse af de store vandarealers flora og fauna. Således var de vældige tagrørsbevoksninger, som før afvandingen fandtes $i$ marsken, af stor betydning som indtxgtskilde for beboerne her. Store mængder af tagrør blev sejlet til Tønder eller Højer. Det var især i Gudskog, at man skar tagrør, og herfra hentede man også - selvom man boede i ret stor afstand fra Gudskog hø til de få kreaturer, som man havde.

Marskens vandløb og søer var inden afvandingen overordentlig fiskerige, og selv i de små kanaler, der førte helt op til husene, kunne der fanges fisk. Det var især ål, men der fandtes dog også aborrer, gedder, karper og - i Vidåen - laks.

Men den omstændighed, at befordring til lands var enten umulig eller meget vanskelig, gjorde, at en del af marskboerne delvis ernxrede sig ved at transportere andres gods. Det var især i Rudbøl, at der var et stort antal af de såkaldte "bådmænd «. I 1830 var her 30 bådmænd, som hovedsagelig gav sig af med bådfart til og fra Tønder - fra skibe, der ikke kunne sejle helt op til byen - eller til Højer. Da skibsfarten på Højer døde hen, ophørte også bådfarten med gods til Tønder, men indenfor marskomrădet foregik dog megen transport ad vandvejen endnu i nogle år efter 1900. Det, der transporteredes, var f. eks. mursten, der produceredes i teglværker i marsken eller på geestranden, og klinker, der $\mathrm{i}$ årene omkring 1900 anvendtes til belægning af de større veje i marsken.

Skildringen af marskboernes liv indeholder bl. a. en omtale af udnyttelsen af sumpplanter som søkogleaks (»pægge«), dunhammer (»fleg «) og pindsvineknop (»jaller «). Af disse planter fremstillede man måtter, sivsko og bånd til eget brug og til salg. Afsnittet om marskboerne afsluttes med en beskrivelse af, hvorledes beboerne i bl. a. Rudbøl og Rosenkrans klarede det for marskboerne vanskelige problem med at skaffe sig drikkevand, før man i 1959 fik indlagt vandværksvand $i$ husene. Vandet, som hentedes fra kanaler, grøfter og damme, var ikke godt, og nogle steder filtrerede man det derfor gennem en kegleformet filtrerkumme af en porøs sten.

Andreas Møller har gennem den foreliggende bog formået at få marskboernes liv før af vandingen til at træde overmàde levende frem for læseren. Hertil bidrager bl. a. de mange meddelelser, hvorigennem gamle marskboere beretter om, hvad de husker om livet $\mathrm{i}$ tidligere tid. Men det, der især præger bogen, er det meget store antal ganske udmarkede og historisk interessante fotografier, som ikke alene illustrerer marskboernes erhvervsliv, men som også giver nogle fortræffelige indtryk af bebyggelserne og naturforholdene. Hertil kommer en rakke tegninger af de redskaber og brugsgenstande, som man anvendte.

Fremstillingen er ledsaget af flere smukt udførte og instruktive kort og kortskitser. Blandt disse sidste må nævnes et gammelt kort, 
hvorpå der foruden et par veje er afsat den vandvej (»fargrøft «), ad hvilken folkene fra gårdene Sydfelt og Emmerløkke hentede varer $\mathrm{i}$ det nærliggende Møgeltønder.

"Både og bådfolk i marsken « er et værk, som vil være af stor og blivende værdi for forståelsen af, hvorledes livet har formet sig i dette område, der - som der står $\mathrm{i}$ indledningen - "er et enestående eksempel på erhvervslivets tilpasning til det naturlige miljø».

N. H. Jacobsen

Gerd Callesen: Socialdemokratiet og internationalismen. KIlder til belysning af det danske socialdemokratis syn pả det slesvigske sporgsmál 1906-24.

Forlaget Fremad 1973, 40 sider, ill.

Som en berettiget reaktion på den megen kritik af den svage placering, arbejderbevægelsens historie hidtil har haft i skoleundervisningen, har forlaget Fremad i samarbejde med Selskabet til forskning i arbejderbevægelsens historie i 1973 udgivet de første tre kildeh $x$ fter med emner fra dansk arbejderbevægelses historie. Hæf terne tænkes brugt $\mathrm{i}$ undervisningen $\mathrm{i}$ gymnasier, $\mathrm{HF}$, seminarier $o$. lign. Men dette hxfte, der beskxftiger sig med det danske socialdemokrati og det slesvigske spørgsmål, har selvsagt en særlig interesse for sønderjyske læsere, også uden for undervisningsinstitutionerne.

Udgiveren dr. phil. Gerd Callesen har hermed påny taget det emne op, han har behandlet i sin disputats til Kiels universitet, trykt i 1970 med titlen Die Schleswig-Frage in den Beziehungen zwischen dänischer und deutscher Sozialdemokratie von 1912 bis 1924. Ein Beitrag zum sozialdemokratischen Internationalismus. Denne bog vakte ved sin fremkomst megen debat både på tysk og dansk side. Der skal her især henvises til G. Japsens kritik i Sønderjyske Årbøger 1971. Af den nye kildesamling fremgår imidlertid, at Callesen ikke på noget punkt synes at have kunnet acceptere den dengang fremførte kritik, der i høj grad også er relevant for dele af denne bogs kildeudvalg og kommentering. For den lærer, der vil anvende kildesamlingen $i$ sin undervisning, vil det derfor være nyttigt at sxtte sig ind i debatten fra 1970-71, selv om forlaget optimistisk reklamerer med, at $\$$ kildematerialet udgør en selvstændig enhed og forudsætter ikke lærebøger eller supplerende materiale«.

Hxftets indhold dxkker perioden 1906-24 og koncentrerer sig om debatten $i$ det danske socialdemokrati. Det indeholder tillige en hel del stof om det slesvig-holstenske og særlig det nordslesvigske socialdemokrati. Bortset fra et enkelt afsnit skal kildeudvalget ikke diskuteres i detaljer her; men folgende generelle betragtninger vil nok være på sin plads. 
I udgiverens forord hedder det: »Kilderne i hxftet er et udvalg. Det kan betyde, at kilderne måske ikke er repræsentative. Hvis man f. eks. havde taget andre kilder om samme emneområde, kunne man måske have fået et modificeret/andet billede af den historiske virkelighed." Hermed antydes vel, at udgiveren har været forberedt på kritik af kildesamlingen, og det må da også være et naturligt krav for brugeren af et sådant hæfte, at udvalget er nogenlunde reprasentativt. $\mathrm{Og}$ det er netop på dette punkt, at hæftet har en svaghed. Alligevel loves der $\mathrm{i}$ forordet, at der ikke er "forsøgt at give et entydigt billede af udviklingen, men at lade de virkelige modsæetninger fremtræde. " Disse ord lover imidlertid mere, end der holdes. Kildehæf tet er nemlig koncentreret om hovedproblemstillingen: Hvordan mener Socialdemokratiet, at partiet ideelt bør forholde sig til grænsespørgsmålet, og hvordan svarer den faktiske politik til det internationalistiske ideal? Men for udgiveren synes der ikke at være nogen stor forskel på det oprindelige ideal og den faktiske politik. Der bringes gode kildeeksempler fra den teoretiske diskussion i partiet, særlig fra debatten under 1. verdenskrig; men belysningen af den faktiske politik er helt utilstrækkelig. Udgiveren synes på forhånd at gå ud fra, at den socialdemokratiske politik i gransespørgsmålet skal fortolkes som en virkning af en internationalistisk ideologi i partiet, og han forsøger derfor ikke $\mathrm{i}$ kommentaren at placere grænsepolitikken $i$ en bredere sammenhæeng $f$. eks. med partiets udvikling $i$ almindelighed og med de skiftende inden- og udenrigspolitiske forudsætninger. Den læser, der ikke på egen hånd skaffer sig den nødvendige baggrundsviden, er fuldstændig henvist til at vurdere på udgiverens betingelser. Men faktisk er hæftets titel »Socialdemokratiet og internationalismen * alt for prætentiøs. Internationalismens betydning for det danske socialdemokrati kan næppe fastslås ved så stærkt at isolere dets holdning til det slesvigske spørgsmål, der aldrig var et hovedproblem for partiet.

Med disse mangler må hæftets pxdagogiske anvendelighed forekomme stærkt formindsket. Der stilles forskellige vejledende sporgsmål til kildematerialet af udgiveren, som skal forsøges besvaret af brugeren. Men ofte kan disse spørgsmål ikke besvares forsvarligt ud fra selve hæf tet, og et par steder er de direkte ledende. Hertil kommer, at der kun i meget ringe grad lægges op til almene metodiske overvejelser i forbindelse med anvendelsen af forskellige kildetyper, og i det hele taget mangler kontrasteringen af forskellige kildetyper.

Megen af den anførte kritik kan imidlertid føres tilbage til, at kildehæf tet forsøger at dxkke for lang en periode. Der er simpelthen ikke plads til ret mange kilder $i$ hvert afsnit. En udeladelse af det meget stof om det slesvig-holstenske broderparti og en koncentration af kildeudvalget omkring f. eks. 1914 (el. 1918) - 1920 ville sikkert have været en fordel. Netop afstemningstiden kunne meningsfuldt 
være blevet det centrale afsnit, fordi idealerne her for alvor skulle forsøges omsat i praktisk politik. Et afsnit findes dog også herom med titlen "Reaktionen på afstemningssituationen $i$ en nordslesvigsk partiforening marts 1919 - marts 1920 «. Men det er desværre blevet helt utilstrækkeligt. Trods titlen forsøger dette afsnit at belyse hele det nordslesvigske socialdemokratis og til dels også det danske partis stilling $\mathbf{i}$ afstemningstiden. Men det sparsomme kildeudvalg tjener ensidigt det formål at underbygge forfatterens yndlingstese, at socialdemokratierne ikke reagerede på afstemningssituationen som danske eller tyske partier, men tværtimod holdt sig neutrale.

Imidlertid findes der netop fra afstemningstiden et fyldigt materiale, hvor meget så stærkt peger på det slesvig-holstenske socialdemokratis tilknytning til Tyskland, en ganske naturlig følge af dets historiske oprindelse. Men intet i kildeudvalget røber den stærke agitation, det slesvig-holstenske parti førte til fordel for tysk stemmeafgivning, en agitation, der på ingen måde veg tilbage for en nationalistisk argumentation. I kildeudvalget aftrykkes uddrag af et brev fra det danske socialdemokratis sekretær Alsing Andersen til P. Michelsen, Flensborg, fra 30. juli (ikke juni som anført) 1919. I uddraget er udeladt netop det afsnit, der kritiserer denne agitation, og som lyder således i oversættelse: "Endvidere benytter jeg denne lejlighed til at bede Dem om, at De vil følge Deres egne ord og arbejde for, at den bitterhed, som så let opstår under de nuværende omstændigheder, får mindst mulig næring. Og navnlig kan De utvivlsomt såvel over for partiledelsen som ledelserne af lokalforeningerne modvirke al agitation, der kan opfattes som fjendtlig over for Danmark. På et tidligere stadium er der blevet fremsat udtalelser både $\mathrm{i}$ taler og $\mathrm{i}$ flyveblade om og imod Danmark, der næppe var nødvendige, ja endog ikke gavnlige. De har skabt bitterhed på begge sider af grænsen. " Hvorfor har et så vigtigt afsnit skullet udelades? Ikke alene er det videnskabeligt set betænkeligt; men den pædagogiske værdi af et kildeudvalg, der er arrangeret efter sådanne principper, forekommer også stærkt begrænset.

Den erklærede pædagogiske hensigt med et kildehæfte af denne type er nemlig at bringe modstridende og forskelligartede udsagn $i$ kontrast med hinanden og derved give brugeren færdighed $i$ at vurdere en argumentation og selv prøve at nå til en konklusion. Før dette afsnit giver udgiveren da også denne vejledning: "Det bør selvfølgelig overvejes, om der var overensstemmelse mellem resolutionernes smukke ord og de faktiske handlinger. « Men dette spørgsmål har bogens brugere ikke en chance for at tage stilling til på grundlag af dette ensidige kildeudvalg og kommentarer.

Det ville ellers have været oplagt at kontrastere det slesvig-holstenske SPD's opråb fra foråret 1919 "Schleswig-Holsteiner! Stimmt deutsch! « med den resolution fra 26. okt. 1919, der blev vedtaget af 
repræsentanter fra partiforeningerne i Haderslev, Åbenrå, Sønderborg og Tønder kredse (ikke fra alle foreningerne i 1.og 2. afstemningszone som anført) på initiativ af den slesvig-holstenske partiledelse. I denne, iøvrigt aldrig offentliggjorte resolution, erklærer partiforeningerne sig for inkompetente til at tage stilling $i$ den nationale kamp. I forbindelse med denne resolution burde kommentaren have redegjort for det danske socialdemokratis bestræbelser i 1919 for at fremkalde en mere neutral holdning til afstemningsspørgsmålet hos broderpartiet, således at det var muligt for læseren at placere den i den rette sammenhæng.

Det ville også have været en god idé at trykke mindst ét af den dansksindede haderslevsocialdemokrat Jørgen Møllers breve, der er trykt i Sønderjyske Årbøger $\mathrm{i}$ år, for disse breve giver nemlig rigeligt stof til kontrast med det øvrige kildeudvalg. Endelig kan man sige, at der burde være taget mere stof med om det danske socialdemokrati, som hele kildesamlingen jo sigter på.

Selv om det er beklageligt, er det vel ikke helt uforståeligt, at Gerd Callesen har ladet sin nye bog i høj grad forme sig som et svar til kritikken af disputatsen. Men dette kildeudvalg har ikke overbevisende kunnet dokumentere, at socialdemokratiernes holdning til det slesvigske spørgsmål har været så entydig, som Gerd Callesen mener.

Dorrit Andersen

\section{Aage Trommer: Modstandsarbejde I nærbillede.}

Odense Universitetsforlag 1973. 515 sider.

Dr. Trommers bog om region III's historie er meget udførlig. I 13 kapitler og en konklusion på ialt 400 tæt trykte sider, der har større format end normal bogside, gøres rede for alle - gentager alle - begivenheder i det sydjyske område, som region III omfattede.

De sidste 100 sider er kilde- og litteraturfortegnelse samt et noteregister, der giver mange spæendende oplysninger, og et person-, sagog stedregister, der gør det let at finde rundt $i$ bogen.

Dr. Trommer holder $\mathrm{i}$ denne bog samme grundige linje som $\mathrm{i}$ bogen om jernbanesabotagen. Alle spor er nøje fulgt, alle oplysninger kritisk vurderet, alt er taget med, så man kun kan beundre det uhyre forarbejde, der er gjort. Forfatteren har talt med næsten 450 personer, der har været med i modstandsarbejdet, og selv om man kun kan skønne om, hvor mange der deltog aktivt, så må de nævnte 450 $i$ al fald anses for et bredt og dxkkende udsnit af de mennesker, der kendte noget til begivenhedernes forløb $\mathrm{i}$ krigens tid.

Region III er ikke kun Sønderjylland med grænse ved Kongeån; den omfattede også området nord herfor til en linje Fredericia- Esbjerg, Varde. Under krigen varierede regionens nordlige grænse no- 
get, men der er aldrig tale om en ren nordslesvigsk region, og »Højland Christensen gjorde heller ikke $\mathrm{i}$ sine dispositioner nogen forskel mellem det gamle og den genvundne land. Det var region III, han var chef for."

Selv om det er region III's historie, tager bogen sin begyndelse længe før, der fandtes regioner. Det første modstandsarbejde, der fandt sted, blev øvet af kommunister; de blev jo kastet ud i det, da deres parti blev forbudt. De blev forfulgt, de måtte gå under jorden, hvis de ikke ville ende i Horserødlejren eller Vestre fængsel. Drivkraften for dem var viljen til at overleve og mere kampen mod nazismen end kampen for Danmark, men de var $\mathrm{i}$ gang, mens den borgerlige del af befolkningen nøjedes med at knytte hænderne $i$ lommen cg følge kongens og regeringens bud, hvor svart det end kunne falde mange. For det borgerlige element var motivet for at gå ind $\mathrm{i}$ modstandskampen et ønske om at udviske den ydmygelse besættelsen $d$. 9. april havde været, og et ønske om at Danmark atter kunne blive et frit land.

Disse to forskellige indstillinger gav en vis gensidig mistænksomhed $\mathrm{i}$ arbejdet, der vel nok mest kom til udtryk jo højere $\mathrm{i}$ ledelsen, man kom. I grupperne ude på baneskråningerne spekulerede man ikke så meget på, hvad farve kammeraten havde; her var man ganske enkelt nødt til at stole på hinanden. I Frit Danmark grupperne gjaldt det samme forhold, og de problemer, der kunne skille, lod man i nogen grad ligge. Som krigen skred frem, og der blev opnået kontakt til London, en kontakt der særligt var på borgerlige hænder, og det derfor blev de borgerlige, der sad på våben og sprængstof, medforte dette forhold, at man blev tvunget til et samarbejde, der forløb godt, men mistænksomheden vedblev at bestå.

Region III blev kaldt »den lille region med de store vanskeligheder ", og til vanskelighederne hørte, at der ikke var nedkastningspladser $\mathrm{i}$ regionens område; der havde været undersøgt muligheder for egnede pladser, men man opgav dem af sikkerhedsmæssige grunde, man var betænkelig ved en sådan virksomhed i nærheden af hjemmetysk beboelse.

Regionen havde derfor lange forbindelseslinjer, for $\mathrm{i}$ krigens tid var der langt fra nord til syd i Jylland, når det drejede sig om illegale transporter, derfor var regionen konstant underforsynet med våben og sprængstoffer.

I sommeren 1943 kom de forste forsyninger, en kurer bragte to kufferter til Tønder. Denne beskedne leverance blev som tiden gik, dog betydeligt forøget, $\mathrm{ja}$ endog med så store mængder, at Gestapo $\mathrm{i}$ området fik beslaglagt $1700 \mathrm{~kg}$ sprængstof, og her er vi ved en anden vanskelighed for regionen, nemlig de mange arrestationer. To gange lykkedes det Gestapo at opnå store resultater. To gange blev regionen stort set rullet op, og mange steder blev arbejdet lammet for kortere 
eller længere tid. Det er beundringsværdigt, at ledelsen bestandig havde kraft og mod til atter at opbygge en organisation, der for hvert slag blev større og stærkere.

Regionens tab var store. Efter oplysninger fra Gestapochefen i Kolding, blev der $\mathrm{i}$ regionen fra 15/9 43 til krigens afslutning taget ca. 1.350 fanger, og i dette tal er ikke medregnet gendarmerne.

Lykkeligvis klarede størsteparten krigens sidste tid som fanger i Frøslev, nogle blev løsladt, de "var illegale forbiere", men 49 døde i kz-lejre eller under anholdelser, og 15 blev henrettet. Det var store tabstal, og de ca. 1300 svarer til ca. $25 \%$ af den styrke, regionen kunne mønstre, da den ved krigens afslutning var størst.

Det skal nævnes, at de mange arrestationer ikke skyldtes tilstedeværelsen af hjemmetyskere, kun et enkelt tilf $x$ lde kan henføres til hjemmetysk angiveri, og at der var hjemmetyskere i regionens område, var måske medvirkende til, at modstandsfolkene var mere forsigtige, end de ellers ville have været, og det kunne nok tiltrænges. "Securitien var generelt blandt borgerlige modstandsfolk et svagt punkt.«

Dr. Trommer har foretaget en undersøgelse over, hvor modstandsbevægelsen rekrutteredes fra, og han hævder, at det er yderfløjene på den politiske arena, der især var aktive. M.h.t. kommunisterne har han ret, men når talen er om det borgerlige element i Nordslesvig, mener jeg, uden at ville forklejne Dansk Samlings indsats, at han tillægger dette parti for stor indflydelse. For modstandsbevægelsens medlemmer var partipolitik uendelig ligegyldig. Motiverne for at gå ind $i$ aktiv kamp var som næunt ønsket om at udviske skammen fra d. 9. april, ønsket om at leve $i$ et frit land, og det var onsket om at bekæmpe diktaturet med alt, hvad dette indebar af terror og ondskab, og denne indstilling var naturligvis først og fremmest at finde blandt ungdommen. Når dr. Trommer konstaterer, at det var folk med tilknytning til Sct. Georgsgilder og terrænsportbevægelsen, der meldte sig, så er det, fordi disse organisaticner bestod af unge. Han benævner dem Tordenskjolds soldater, for de var gengangere $\mathrm{i}$ disse organisationer, men de var også medlemmer i Det unge Grænseværn, $i$ ungdoms og idratsforeninger, og de var af vidt forskellig politisk opfattelse; der var maskinarbejderen med tilknytning til Socialdemokratiet, der var den unge landmand med tråde til Venstre o.s.v. Kort sagt, det var den nye generation, der stod parat til at gøre en indsats i det grænsepolitiske arbejde, det var den ungdom, der havde levet med $\mathrm{i}$ de bevægede år op til krigen, der var blevet dansk nationalt bevidste ved konfrontationen med nazismen, den ungdom, der havde valget i 1939 i frisk erindring, hvor de havde følt, de havde været med til at bekræfte deres tilhørsforhold til Danmark, det var denne ungdom uanset partipolitiske sympatier, der rekrutteredes til modstandsbevægelsen. 
Jeg er derfor ikke enig med dr. Trommer, når han siger, - "Sagen sat på spidsen - - at Nordslesvig ikke så meget skabte sin egen modstandsbevægelse - men fik den påtrykt udefra - nordfra «, og dette støttes på hans iagttagelse af det stærke kongerigske islæt, som han vist overvurderer.

Der ville efter min mening ganske givet være opstået en modstandsbevægelse i Nordslesvig alligevel, den var ikke afhængig af folk, der var flyttet til landsdelen efter 1920, og det var ikke deres fødested nord for Kongeåen, der medførte, at de, der iøvrigt ikke følte sig særlig "kongerigske", var med blandt de første.

Og her kommer vi til en anden konklusion i bogen, hvor jeg heller ikke er enig med forfatteren, nemlig hvor han mener, at svælget mellem de gamle ledere og modstandsbevæagelsen "- måske til en vis grad kan forklares med det forhold, at det illegale arbejde i landsdelen ikke mindst i den indledende fase lededes af folk af kongerigsk afstamning."

Hverken dette forhold eller det, at nogle af de illegale ledere havde tilknytning til de politiske yderfløje, har noget med dette problem at gøre. Skellet mellem de gamle nationale ledere, representeret i Dansk Samråd, og modstandsbevægelsen skal søges i den helt fundamentale opfattelse af, hvorledes man skulle hævde sin danskhed, og her sad medlemmerne i Dansk Samråd inde med en personlig erfaring fra udlændighedstiden, hvorledes man skulle yde passiv modstand. Denne form for national modstand, der faldt sammen med kongens og regeringens bud om at forholde sig $\mathrm{i}$ ro, var $\mathrm{i}$ overensstemmelse med deres synspunkt, hvorfor de kun kunne fordømme sabotagehandlinger.

Dansk Samråd havde i sommeren 1940 besluttet at være et kompetent organ for den samlede danskhed $i$ Nordslesvig, der under hensyn til de muligheder, der var for pludselige begivenheder $\mathrm{i}$ besæettelsestiden, kunne optræde som talerør for danskheden.

At Dansk Samråd helt stod på regeringens linje, og at man havde landsdelens dansksindede befolkning bag sig i krigens forste år, er hxvet over enhver tvivl; men da begivenhederne udviklede sig, sabotagen voksede i omfang, forstod man ikke i Dansk Samråd, hvad der rørte sig i befolkningen. Sxrligt ikke de medlemmer af samrådet, der tillige var rigsdagsmedlemmer og med stærke - for stærke og for fordømmende - udtalelser om det skadelige i sabotage og illegale skrifter, lagde en stor afstand mellem sig og modstandsbevæegelsen. De onskede, at Nordslesvig skulle være den roligste del af landet. At Dansk Samråd efter d. 29. august, med de kontakter man havde til Christiansborg, og med de medlemmer, der repræsenterede det folkelige, ikke forstod, at situationen nu var en ganske anden, og at samrådet ikke, som det skete på landsplan, hvor der skabtes kontakt mellem politikere og frihedsråd, fik skabt kontakt til region III, kan 
undre. Måske ønskede ingen af parterne rigtig kontakten; måske var kløften mellem dem blevet for dyb at bygge bro over. Fra begge sider var sagt ting, som skulle have været usagte, og det blev derfor modstandsbevægelsen alene, der kom til at præge befrielsen, skønt det givet ville have været af værdi, hvis der havde været et besindigt følgeskab fra Dansk Samråd til at deltage i de beslutninger, der blev taget, da freden oprandt.

Man kan beklage, at bogen slutter med befrielsens dag, der dog ikke var den dag, regionen ophørte, for det ville have været interessant at have sommeren 1945 med, et tidsrum, hvor regionen også spillede en rolle. Disse sommermåneder har jo fået forskellig vurdering, fra professor Troels Finks forsigtige: "Det gjorde de dårligt « til røster, der talte om gadens parlament.

Her ligger altså en opgave for en historiker at belyse sommeren 1945 i Nordslesvig, et tidsrum, der hører med i landsdelens historie på godt og ondt.

Det er en god bog, det er en redelig bog, og den er velskrevet med kritisk sans, med plads til fantasi, men den vil sikkert for en del af dem, der deltog og husker de beskrevne begivenheder, virke for strengt saglig. Dr. Trommer er blevet angrebet for at ville nedvurdere modstandsbevæegelsen og dens indsats. Det indtryk sidder man ikke tilbage med, når dette digre værk lægges væk, og at det $i$ al fald ikke har været dr. Trommers hensigt turde være klart, for i så fald havde han næppe på bogens første side sat det stolte citat "Act well thy part, there all the honour lies.«

Poul Andersen

\section{Aage Trommer. Jernbanesabotagen i Danmark.}

Odense Universitetsforlag 1971. 323 sider.

Da dr. Hæstrup i 1960 satte sin unge medarbejder lektor Aage Trommer ind på den opgave at skrive Region III's historie, stod det ingen steder skrevet, at dette arbejde skulle resultere $\mathrm{i}$ en disputats om jernbanesabotagen i Danmark. Der gik mere end 10 år, inden disputatsen kunne forsvares ved Odense Universitet, men der ligger også et uhyre forarbejde bag denne bog på over 300 sider.

Med megen interesse havde modstandsfolk ventet på dette arbejde, og mange blev skuffede, hvilket også kom til udtryk over for doktoranden ved afhandlingens forsvar, hvor en del opponerede ex auditorio.

Ingen af os kan jo lide, at der pilles ved vore idealer eller forestillinger, og nu kom her en videnskabsmand, der med klare og kontante tabeller viste, at de resultater, Montgomery havde betegnet "second to none «, ikke helt kunne holde til denne vurdering. 
Men det er jo en historikers pligt at lade folelserne $i$ baggrunden og belyse kendsgerningerne. Som samtidshistoriker har dr. Trommer haft mange arkiver at hente konkret viden fra, og han har, hvilket fremgår af det omfattende noteregister, ført et vxld af samtaler med mange af de i dette specielle stykke Danmarkshistorie involverede personer; og det må siges, at han er gået til bunds i problemerne. Kurver er optegnede, køreplaner opstillede, togenes kørsel, både mod nord og syd, er omhyggeligt fulgt på det danske skinnenet.

$\mathrm{Da}$ dr. Trommer gik igang med sit arbejde, kendte han de bedømmelser, der forelå fra dr. la Cour, dr. Hæstrup m. fl. om jernbanesabotagen, og det var hans hensigt nu helt nøje at belyse den virkning, den havde, og så skete der det, efterhånden som arbejdet skred frem, at forskeren blev forbavset og nåede til det resultat, at sabotagen »ikke på noget tidspunkt $\mathrm{i}$ krigen var $\mathrm{i}$ stand til at få taktisk, endsige strategisk betydning."

Kendsgerningerne står skarpe uden myternes romantiske klædning.

I et interessant kapitel læser vi om sabotagens taktik. Her er der tale om to principper, efter hvilke man kan skade fjendens kommunikation mest muligt, nemlig attrition, hvilket er en aktion med langvarigt sigte, hvor det gælder om at ødelægge lokomotiver og faste installationer som signalposter og vandtårne, kort sagt slide materiellet ned, så trafik ikke kan foregå; og det andet princip, interception, hvor man sprænger skinner, sporskifter og broer med det formål at standse trafikken $i$ det givne ojeblik.

Disse to principper kendte den menige sabotør kun lidt eller intet til, han angreb det mål, han fik anvist udfra en "sikker overbevisning om, at enhver sabotagehandling mod tyskerne var velbegrundet i sig selv«, og den var i al fald med til at give ham den tilfredsstillelse, at han gjorde noget.

Det synes iøvrigt heller ikke, at ledelsen har reflekteret meget over disse to nævnte principper, og $\mathrm{i}$ de højeste allierede stabe var der stor uenighed om, hvad der var mest effektivt. Når det side 53 oplyses, at de allierede for invasionen anvendte godt 70.000 tons flybomber til attritionsprincippet, uden det lykkedes at bringe den tyske togtrafik til standsning i Nordfrankrig, og at de i de sidste dage inden invasionen brugte ca. 4.000 tons flybomber til sprxngning af Seinebroerne, så forstår man meget vel, at danske jernbanesabotører med deres svage styrker og beskedne beholdninger af sprængstof ikke kunne udrette det ekceptionelle.

De to banestrækninger langs Sønderjyllands øst- og vestkyst hørte til de strategisk vigtigste. Skulle jernbanesabotagen være effektiv, var det her angreb skulle sættes ind, og helst skulle begge strækninger angribes. Da jernbanesabotagen var $i$ sin vorden, var dette ikke muligt; der var ganske enkelt hverken mandskab eller sprængstof hertil.

Først fra efteråret 1943 var sabotagen under faldskærmsmanden 
Ole Geislers ledelse udbygget så meget, at man kunne tænke på større samlede aktioner. En sådan fandt da også sted d. 26. september 1943, hvor grupper i Ålborg, Randers, Århus og Tønder i samme døgn gik til aktion. På det sønderjyske skinnenet lød bombebragene fra 49 steder, og dagen var valgt med velberåd hu, som en fødselsdagshilsen til kongen. En noget lignende aktion pà rent lokalt sønderjysk plan fandt sted d. 28. november 1943 .

Disse sprængninger havde utvivlsom psykologisk virkning, og de gjorde indtryk på besxttelsesmagten. »Fra tysk side blev det opfattet som en demonstration af, hvad man formàede $i$ tilfælde af invasion."

Men selv om sabotagen nu efter kontakten til England var etableret, og faldskxrmsfolk virkede som instruktører og organisatorer, og der var skabt regioner og jyllandsledelse, må det erkendes, at fjendens troppebevægelser med tog foregik ret uberort.

Kapitel $11 \mathrm{i}$ bogen omhandler tyske divisionsflytninger $\mathrm{i}$ tiden juni 1944 til januar 1945. Her er iagttaget ca. 400 tog, mod hvilke der var ca. 90 sabotageaktioner. Bortset fra aktionen mod en Volkgrenaderdivision $\mathrm{i}$ bevægelsen $"$ Tirpitz $\ll$,der kørte $\mathrm{i}$ dagene 8. til 13. november, og som blev forsinket ca. 50 timer, er forsinkelserne af fă timers varighed, og om adskillige bevægelser lyder forfatterens konklusion: $\gg$ Bevægelsen afsluttedes rettidigt. «

Dr. Trommer har mødt megen kritik fra modstandsfolks side, og det er forståeligt. Her var danske mænd af alle afskygninger gået til kamp uden betænkning, gået ind $\mathrm{i}$ en kamp, hvor det meget vel kunne være med livet som indsats, med det formål, "at vore fjenders transporter gennem Jylland blev - om ikke lammede, så dog alvorlig besværliggjort for længere tid.«

Disse folk havde set togene holde timevis ved sprængte skinner, de havde set afsporede vogne ligge over skinnelegemet og spærre for al trafik. En gruppe i Nordslesvig erhvervede Danmarksrekord, da den gennemførte en perfekt afsporing mellem Bolderslev og Hjordkær i september 1944, hvorved al trafik lå stille i 42 timer. Disse resultater kunne da ikke være uden betydning! Dr. Trommer nedvurderer ingenlunde den øvede indsats; men køreplanernes nøgterne tal, arkivernes beretninger og al den viden, han har kunnet hente fra samtiden, blotter kendsgerningerne om svagheder $\mathrm{i}$ ledelsen, og om stadig mangel på sprængstoffer og personel.

Et er jo at konstatere dette $\mathrm{i}$ fredstid 25 år efter begivenhederne fandt sted, et andet er, at sådan var krigen og kampens vilkår, og dr. Trommer erkender da også, at en illegal stabs arbejde og dispositioner ikke kan sidestilles med en almindelig hærs stab. Tilførsel af sprængstoffer var afhængig af leveringer fra England, og den stadige mangel på personel må ses $\mathrm{i}$ konstateringen af, »at en sabotørs illegale »levetid» ofte kun var 1-2 måneder «. Gestapo var energisk, og gang 
på gang lykkedes det at rulle grupperne op, så nye folk uden erfaring og uden kampvante ledere $\mathrm{i}$ marken, selv måtte uddanne sig i deres farlige håndværk. I en rapport fra Bennike til London ydede Bennike en særlig hyldest »til de folk, der arbejder i Sønderjylland « og citerede i rapporten ordene $\gg$ For de gamle som faldt $-\ll$

Tager man alle disse besverligheder $\mathrm{i}$ betragtning, er man imponeret over, at der blev lavet sabotage, og at den voksede i størrelse og effektivitet. Når bogen så er læst, dukker spørgsmålet op: Var det omsonst? Svaret må blive et klart og stærkt: Nej.

Var resultaterne end små, så forklejner det ikke indsatsen, for både politisk og vel ikke mindre psykologisk havde sabotagen betydelig virkning på såvel ude- som hjemmefront.

Den var medvirkende til, at vestmagterne anerkendte os som allieret, at det kæmpende Danmark fik en repræsentant i Moskva, og på hjemmefronten var den medvirkende til at skabe et enigt dansk folk, unge og gamle, der aktivt og passivt gik ind for at bekæmpe nazismen, så Danmark atter kunne blive et frit land. Alt dette kan vi takke også jernbanesabotagen for, som den del af helheden i modstandskampen den var. Det er godt, denne specielle side af modstandskampen er blevet så skarpt belyst.

I rækken af bøger om besættelsestidens historie, »Kontakt med England «, »Til landets bedste « og mange flere, føjer dr. Trommers bog sig nyttigt og smukt ind.

Poul Andersen

Sønderjyllands Højspændingsværk, Andelsselskab, 50 år 1922-1972.

Vojens 1972. 179 sider, ill.

Det overses undertiden, at de materielle faktorer i Nordslesvig forud for genforeningen måtte være betinget af, at landsdelen statsligt hørte til Tyskland, og der stod ingen steder skrevet, at $1920 \mathrm{i}$ visse henseender ville blive en slags »år nul«, da meget skulle revideres og støbes om i danske forme efter ny tidsregning. Kort sagt: man kunne den gang ikke fremskrive med dansk fortegn.

Var genforeningen ikke kommet på dette tidspunkt, havde vi heller ikke fået et Sønderjyllands Højspændingsværk. Der var før første verdenskrig ved at blive udarbejdet planer om at skabe en falles elforsyning for hele Slesvig-Holsten, men krigen 1914-18 kuldkastede dette som så mange andre projekter. Efter 1920 skulle man derfor begynde næsten på bar bund m.h.t. strømforsyning, men denne udgangsposition førte til gengæld til, at Sønderjyllands Højspændingsværk fik en udvikling, der betegner lidt af et særsyn i landsdelens materielle historie. 
Derfor er en jubilæumsbog om elektriciteten i Sønderjylland som den, Sønderjyllands Højspændingsværk udsendte ved sin 50 års dag i 1972, et bidrag til landsdelens materielle historieskrivning, og som sådan vil den blive bedømt her. Mine bogtekniske bemærkninger skal kun gå på, at formatet er lovlig stort, og alt det, man kalder lay-out, er vel meget præget af reklamebureau, lidt for »smart « for en af Sønderjyllands største virksomheder, der ikke behøver »PR «, men tværtimod altid har haft folkelig opbakning. Sønderjyder kan bedre lide det rolige og værdige end de mange farvede streger og krummelurer.

Men heldigvis har Sønderjyllands Højspændingsværk allieret sig med faghistorikere til udarbejdelse af de mange facts, der skal samles ved en sådan lejlighed og fremstilles oversigtligt $i$ et sobert sprog uden modepræg. I dag tales der meget om atomkraftværker, og det kan derfor synes længe siden, at man i begyndelsen af 1900-tallet så småt begyndte at tale elektricitet i Danmark. Cand. mag. Helle Askgaard gør rede for denne gennembrudstid, oplysningstiden om oplysningstiden. Det er morsomt at stifte bekendtskab med en nøgtern bemærkning i bladet »Elektroteknikeren « for 1921: „Ved genforeningen i $1920 \mathrm{kom}$ der til at foreligge den situation, at en del elektriske anlæg, der for en stor del var udført uden særlig omhyggelig kontrol, og ved hvilke der var anvendt andre installationsmåder end de her $i$ landet hævdvundne, skulle underlægges dansk administration «-Så kort og så afladet for følelser kan en del af genforeningens historie skrives!

Men, hvad enten det er i kurs eller ej, må man idealisere lidt. Elsagens dygtige og utrættelige pionér i Sønderjylland er Jes Christiansen, direktør for Sønderjyllands Højspændingsværk fra 1924 til 1961, og den mand, der har ført såvel el-sagen som de kraftmæssige forsyningskilder frem til højden af i dag. Jes Christiansen var født i Blans og havde i 1914 taget sin eksamen ved den tyske ingeniørskole $\mathrm{i}$ Mittweida. Det er et stort, men nødvendigt ord at bruge, at denne mand var preget af fremsyn. Arkivar, cand. mag. Dorrit Andersen, fremhæver med rette $i$ afsnittet om Nordslesvigs elektrificering $i$ årene 1918-1925, at Christiansen tænkte $i$ store baner og straks agiterede for, at hele landsdelen skulle forsynes under ét. Det kan lyde selvfølgeligt, men baggrunden var, at der dengang lå små jevnstrømsværker $\mathrm{i}$ købstæderne, flækkkerne samt $\mathrm{i}$ enkelte stationsbyer, mens visse nordslesvigske landbrugsområder forsynedes direkte fra Flensborg via 17 transformatorstationer.

$\mathrm{Da}$ de nødvendige forsyningsselskaber $\mathrm{i}$ landsdelen var dannet, kunne det første højspændingsværk bygges ved Åbenrå havn. Det virker imponerende $\mathrm{i}$ dag, at bygge- og installationstiden kun stod på fra 12. december 1922 til 24. oktober 1924. Værket var opført med Eriksen \& Sardemann som projekterende ingeniører i samarbejde med Christiani \& Nielsen. Arkitekt var Jep Fink, Åbenrå, og mens talen 
er om det kunstneriske, er det værd at nævne, at den "prosaiske“ maskinhal udsmykkedes med store kalkmalerier af Troels Trier, Vallekilde. Det "gamle« værk er blevet udvidet mange gange, efterhånden som forbruget steg, og i 1958 måtte der bygges et helt nyt værk, Enstedværket, for at klare forbruget. $\mathrm{Nu}$ er man ved at projektere et tredie, endnu større el-værk ved Åbenrå fjord.

Det er meget godt, at man taler om den »rene « elektricitet, det hvide guld, men Sønderjyllands Højspændingsværk har rigtignok haft forureningsproblemer - og det ikke kun i nyere tider, hvor man har indtryk af, at kan man ikke finde andet at snakke om, så kan man da drøfte forureningen. Den store skorsten ved Åbenrå havn var slem til at sende sod og snavs ud over vasketøj og ind gennem vinduessprxkker. Denne skorsten blev derfor af folkeviddet døbt "Skiern Jes « (Skidne Jes), en anden form for cadeau til direktøren! Det er helt rigtigt, at bogen medtager den kritik, der hele tiden er kommet til orde angående forureningsspørgsmålene, hvilket jo også giver anledning til at fortælle åbenråerne noget om, hvad der er gjort for at bekxmpe støv- og støjplager. Nogle karrikaturtegninger i »Skiern Jes «-stilen fastholder det folkelige lune, som trods alle skærmydsler altid har været den anden side af denne vanskelige sag. Til det anekdotiske stof hører, at når folk klagede over, at de havde fäet en rblehave sodet til, sendte Jes Christiansen dem $i$ al hast en kasse frugt. Der måtte bare ikke tales for meget om det, for alle mennesker kunne ikke så godt få erstatning.

En vigtig og meget positiv side af Sønderjyllands Højspændingsværk's historie er prispolitikken, der igen har forbindelse med samarbejdet med tyske el-værker syd for grænsen. Jes Christiansen forstod at sælge den strøm, han producerede, billigst muligt. Gang på gang gjorde han sig til talsmand for storre forbrug af elektricitet, $f$. eks. til »miljøvenlige« el-køkkener, for når forbruget steg over bred front, ville prisen også blive lavere. Denne sag var på dagsordenen på en generalforsamling i Sønderjyllands Højspændingsværk i 1933, og da direktøren rigtig havde fremmanet masseproduktionens velsignelser også for forbrugerne, rejste en andelshaver under stor jubel spørgsmålet, hvor stort forbruget da skulle være, for at man kunne få elektriciteten helt gratis! Bag en sådan såkaldt kvik bemærkning ligger den sandhed, at Sønderjyllands Højspændingsværk i kraft af en fornuftig tarifpolitik altid har kunnet holde en relativt lav strømpris. Det fik el-køkkenerne til at vinde tidligere frem i de sønderjyske landdistrikter end andre steder $\mathrm{i}$ landet, ligesom el-prisen naturligvis har været en faktor ved industrialiseringen af Sønderjylland efter 1945.

$\mathrm{Nu}$ skal denne anmeldelse ikke kun være Jes Christiansens saga, og der kan derfor være grund til at slutte med et par ord om de dygtige medarbejdere og den samarbejdende og fremsynede bestyrelse, han 
havde. En vigtig side af karakteristikken af Sønderjyllands Højspændingsværk er, som det nævnes i forordet, den kendsgerning, at der gennem de forløbne godt halvtreds år kun har været tre direktører, som har afløst hinanden. Direktør J. Poulsen, nu Vestkraft, Esbjerg, afløste Christiansen i 1960 og sad i Åbenrå til 1. 4. 1972. Derefter tiltrådte $\mathrm{K}$. Fischer som direktør. Andelsselskabets første formand var stiftamtmand C. L. Lundbye, Haderslev, der efterfulgtes af folketingsmand Jørgen Gram, Gabøl. Johan Philipsen, Lundtoftbjerg, havde været formand en årrække og nåede at komme i skudlinien ved et borgermøde $\mathrm{i}$ Åbenrå om betimeligheden af at placere endnu et storværk ved den skønne Åbenrå fjord, da hans udnævnelse til minister $i$ følge reglerne tvang ham til at trække sig tilbage. Vinteren 1974 tiltrådte herefter direktør Thorvald Jensen, Vojens.

\section{Eskild Bram}

Poul Kürsteln (udg.): Barn I Flensborg 1890-1920. Af Ernst Christiansen, Katl Svensson, Jens Schroder, Valborg Jacobsen, Tage Jessen, Anton WestergaardJacobsen, Hakon Thomsen, Jacob Kronika, Marie Elsbeth Miang, Knud Johansen, Svend Johannsen og Kamma Svensson. Sydslesvigske ár og dage.

Forlaget Skandia, Flensborg 1972. 343 sider, ill.

Med Barn i Flensborg 1890-1920 har Studieafdelingen ved Dansk Centralbibliotek for Sydslesvig udsendt en af sine bedste bøger og desværre den sidste, som nu afdøde bibliotekslektor Poul Kürstein kom til at gøre færdig.

Det er ofte erfaret, at erindringsstof vækker interesse $i$ brede kredse, og det er da også i høj grad blevet tilfældet med Barn i Flensborg. På nær to bidrag består bogens 12 afsnit af barndoms- og ungdomserindringer, hvoraf flere i deres helhed er skrevet med særligt henblik på denne bog. Det samlende element $\mathrm{i}$ bogen er naturligvis skildringerne af de nationale forhold i Flensborg og de konsekvenser, de fik for forfatterne, der alle fastholdt deres oprindelige danskhed. Ved læsningen mærker man sig mange pudsige og gribende træk $\mathrm{i}$ beretningerne om barnets første møder med de nationale forskelle og spændinger. Et fælles træk, der findes i næsten alle beretningerne, er erindringen om de chikaner, som børn fra dansksindede hjem udsattes for $\mathrm{i}$ skoletiden, og $\mathrm{i}$ det hele taget om det pres, det ofte var for et barn, at vide sig anderledes end flertallet. Men derudover indeholder bogen mange interessante kulturhistoriske træk fra dagliglivet i Flensborg.

Den del af bogen, der gør stærkest indtryk er imidlertid ikke erindringsbidragene, men derimod Hakon Thomsens dagbog 1913-18, der her udgives for forste gang med titlen "Ung mands tanker om 
dansk og tysk «. Med samtidighedens autencitet sætter disse dagbogsblade erindringsafsnittenes beretninger om lignende forhold $\mathrm{i}$ relief, for erindringerne har naturligt nok ikke altid kunnet undgå en lidt idylliserende atmosfære af "de gode gamle dage

Mindre velegnet $i$ helheden forekommer genoptrykket af Ernst Christiansens to stile fra 1892 og brevvekslingen i forbindelse hermed med M. Andresen og H. V. Clausen. Dette stof har vel hovedsagelig interesse, fordi det fortæller noget om Ernst Christiansen, og ikke sà meget for dets selvstændige værdi.

Skulle man iøvrigt beklage noget ved denne udmærkede bog, skulle det være, at dens forfattere i så høj grad stammer fra samme kreds i det velbjergede borgerskab. Herved kunne læseren få det utilsigtede indtryk, at danskheden i Flensborg før 1920 kun trivedes i en ganske snæver cirkel, og det var dog ikke helt tilfældet. Men det skal indrømmes, at det er svært nu at samle erindringsstof fra tiden før 1920 særlig fra folk, der ikke har været vant til at formulere sig skriftligt eller at reflektere så meget over deres personlige udvikling. Imidlertid skulle der nok ved en fortsættelse af Barn i Flensborg være bedre muligheder for at råde bod på denne skæuhed.

I omtalen af denne bog vil det $\mathrm{i}$ høj grad være på sin plads at fremhæve udgiverens indsats, der er så stor, at Barn i Flensborg også helt igennem må karakteriseres som Poul Kürsteins værk. Et krævende arbejde er udført ved bearbejdelsen af bidragene og med at få forfatterne til selv at udbygge de første forlæg. Et stort og fint billedmateriale er tilvejebragt. Såvel i de lange billedtekster som i de forklarende noter øser Kürstein af sin imponerende store viden om sydslesvigske og flensborgske forhold med en forfriskende ubundethed af puritanske normer for, hvad sådanne tekster og noter bør indskrænkes til. Når Jens Schrøder således s. 64 nævner, at han købte rundstykker hos bager Rerup, så fortæller noten, at bageren var farfar til Studieafdelingens forste leder Lorenz Rerup til oplysning for de læsere, der måtte begynde at grunde over det eventuelle familieskab.

Man må stærkt beklage, at Kürsteins tidlige død forhindrede ham $i$ at fortsætte Barn i Flensborg med et bind om mellemkrigstiden. Forhåbentlig vil det alligevel lykkes Studieafdelingen snart at få et sådant bind fxrdig, for det forste binds fortjente succes syd og nord for grænsen har vist det store behov for publikationer af denne type. Det skal til slut understreges, at Barn i Flensborg er den ideelle gavebog, også til danske bekendte med et ringe kendskab til grænselandets komplicerede forhold, for heri får man værdifuld oplysning om en problematik, der stadig er central for medlemmerne af et nationalt mindretal. 
Flensburg in Geschichte und Gegenwart. Information und Materialien.

Schriften der Gesellschaft für Flensburger Stadtgeschichte e.V. Nr. 22. Flensborg 1972. 469 sider.

Med den foreliggende dokumentation har Gesellschaft für Flensburger Stadsgeschichte forelagt andet bind i sin byhistorie. Første bind "Flensburg - Geschichte einer Grenzstadt« udkom som nr. 17 i selskabets skriftrække i 1966.

Det foreliggende meget alsidige dokumentationsbind er tænkt som en kildesamling, der kan virke som arbejdsmateriale for undervisere og for den interesserede lægmand, både med hensyn til politiske, historiske og geografiske forhold. Der er sørget for, at man ved stofvalget har taget særligt hensyn til dokumentationens lettilgængelighed.

Første sektion i bindet omfatter bl. a. glimt fra Flensborgs forhistorie, indtryk fra byens udvikling til vor tid, derunder Flensborgs funktion i grænselandet. Derefter kommer bidrag, der belyser byen, dens forvaltning og politiske styre. De følges af en sektion om kommunale værker, sygehusvæsen, osv. og et afsnit om skoler og biblioteker. Derefter igen kommer bidrag om partier og organisationer og afsnit om de institutioner, som landsregeringen og forbundet har placeret i Flensborg, og endelig er der er række case-studies, f. eks. Trediveårskrigen og Flensborg, merkantilismen, novemberrevolutionen 1918, slesvig-holstensk revisionspolitik samt en oversigt over mindretalsproblemerne 1945-60. Endelig aftrykkes en lang rxkke kilder.

Den meget store emnespredning gør det muligt for undervisere at finde inspiration til mange indfaldsvinkler på det spændende lokalhistoriske stof fra Flensborg. Men for lægmænd vil dokumentationsbindet nok virke noget uhåndterligt.

Der spores stor fairness $i$ behandlingen af danske forhold i Flensborg, dermed er naturligvis ikke sagt, at de er udtommende behandlet.

Ikke så få kontroversielle emner er inddraget $\mathrm{i}$ stoffet, men der mangler f. eks. en mere udførlig behandling af sager, der har haft stor interesse i Flensborg og ogsà har givet sig udslag i form af heftige politiske kontroverser i Kiel.

Som eksempel skal her nævnes afnazificeringen på godt og ondt samt efterspillet i form af Heyde-Sawade-skandalen. Efterkrigstidens politiske profiler făr man heller ikke meget indtryk af. "Flensburg in Geschichte und Gegenwart « giver mange muligheder for interesserede brugere, men mange af emnekredsene fortjener en særskilt behandling i mindre kildehefter, det gælder f. eks. de erhvervsmæssige og sociale forhold efter 1945, det gxlder splittelsen mellem danske og tyske i byens arbejderbevægelse. Lokal- og regionalhistorie er en uundværlig basis for historien iøvrigt, ikke mindst Flensborg har meget at byde på. Men problemet med hensyn til samtidshistorien er naturligvis, at 
den for nogle nok vil virke lidt for kontroversiel. Så vi skal nok vente mange år endnu, inden man ser en større skildring af en fremtrædende og indflydelsesrig embedsmand som Dr. Kracht.

\section{Anders Ture Lindstrøm}

\section{Hanne Poulsen: Jes Jessen. Maleren fra Åbenrå.}

Udgivet af Historisk Samfund for Sønderjylland. 1971. 208 sider, ill.

Hvor mange kender mon maleren Jes Jessen fra Åbenrå? Hvor kendt er han blandt kunstkendere eller historikere? Undertegnede var $\mathrm{i}$ hvert fald meget uvidende om denne maler (1743-1807), som vi endnu kan finde smukke og interessante vidnesbyrd om fra den tid, han virkede i Äbenrå og den nærmeste omegn.

$\mathrm{Nu}$ har museumsinspektør på Handels- og Søfartsmuseet på Kronborg, mag. art. Hanne Poulsen, skrevet en dejlig, lille bog om Jes Jessen, og jeg vil tro, at mange vil læe den med glæde. Bogen er nok stramt opbygget som en kunsthistorisk afhandling, men sproget er let og flydende, så den er let, jeg kunne sige spændende, at læse. Man făr en klar placering og vurdering af Jes Jessen, desuden får man en indgående behandling af de områder af malerkunsten, som han særlig beskxftigede sig med. Man får en registrering af malerens kendteste værker, og i sidste del af bogen er der en fyldig del med fotografiske gengivelser af disse. Desuden er bogen forsynet med et noteapparat og en litteraturliste. Vigtigt er det, at Hanne Poulsen så tydeligt har bestræbt sig på at placere Jes Jessen på det kunstneriske niveau, hvor han hører hjemme. Selvfølgelig giver en forfatter og specielt den videnskabelige forfatter, så nøgtern en vurdering af sit emne som muligt. - Jes Jessen var ganske givet ikke nogen stor, skabende kunstner. Han var en fin og flittig håndværker, højt agtet $\mathrm{i}$ Åbenrå, og han udførte de opgaver, der blev pålagt ham, om det nu var af kirken, af byen eller af det velhavende borgerskab. Derfor er det Jes Jessens placering i kulturhistorien, der er den virkelig interessante.

Mange kirker i Sønderjylland fik i slutningen af 1700-tallet en kraftig restaurering af kirkerummet. Ofte fandtes der i kirkerne altertavler, der kunne stamme tilbage fra før reformationen, og som nu skulle renoveres. Gammel maling skulle fjernes, nyt træværk skulle »anstryges « og pulpiturer skulle stafferes, ja måske forsynes med billeder fra den hellige skrifts beretninger. Og præster og mæcener, og hvem der ellers kunne bestemme, vidste nok, hvad de ville have. De skønne ting, som man havde set ude $i$ den store verden eller $i$ et af nabosognene, måtte maleren fra Ảbenrå også kunne lave. 


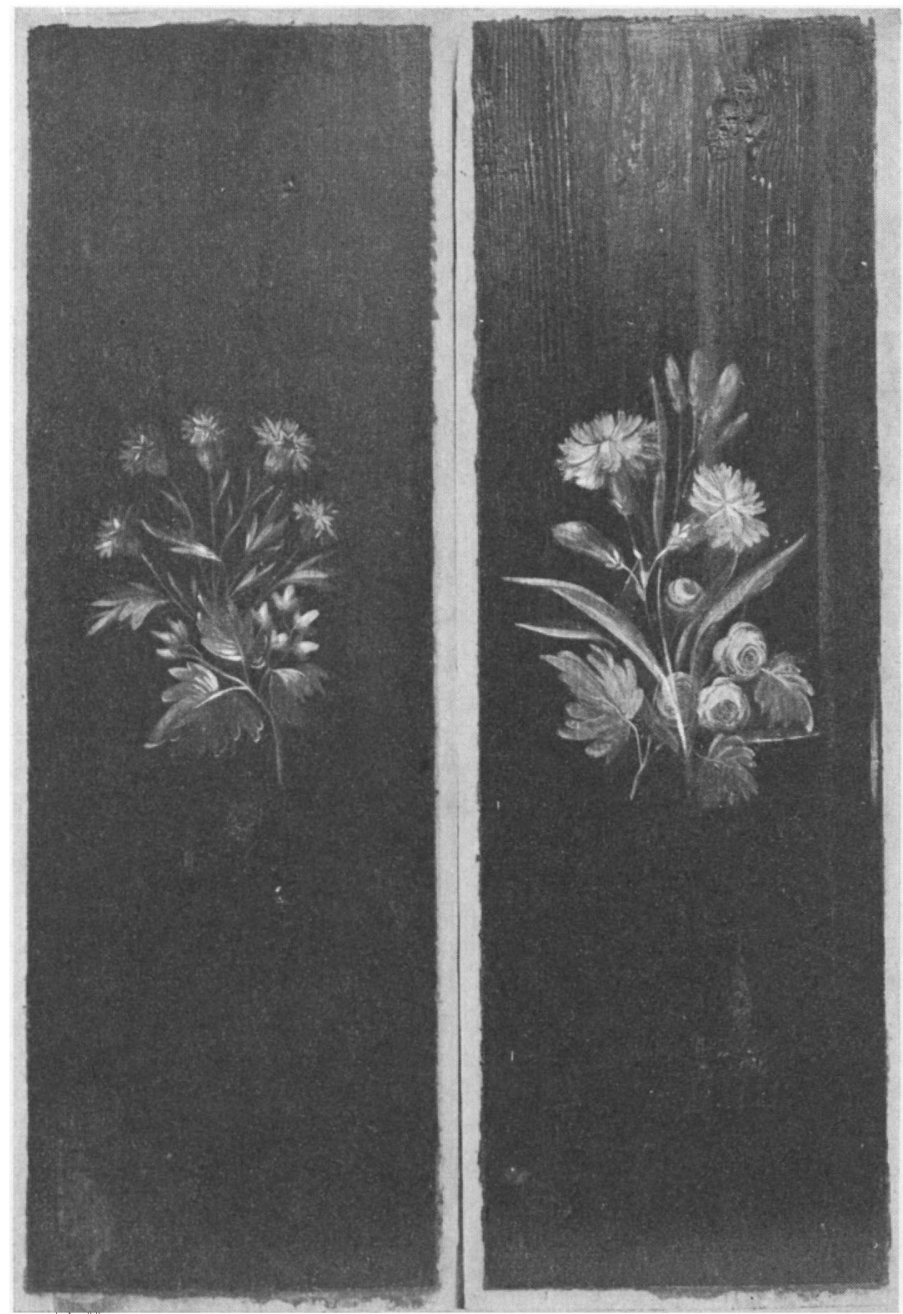

Fyldninger fra stolestaderne i Løjt kirke. Illustration fra bogens side 195.

I Bjolderup, Hjordkjær, Sottrup, Lysabild o. fl. steder har Jessen og hans hjælpere så været virksomme, og skulle alteret forsynes med et nyt billede, tyede man efter den tids skik og brug til et eller andet forlæg. Man brugte kobberstik af så store kunstnere som Rubens, Charles Le Brun eller Jordaens. - Og Hanne Poulsen siger: "Som 
skildrer af den bibelske og den verdslige historie var Jes Jessen en skikkelig kopist «.

Er det så som portrætmaler, at man bør erindre Åbenråmaleren? Nxppe heller. I den sidste halve snes år af sit liv malede han en del portrætter af borgere i Ảbenrå og Randers. Der er naturligvis kvalitetsmæssige forskelle på de enkelte billeder, og nogen egentlig kunstnerisk udvikling viser de ikke. Portrætterne er ret stive og ensartede. Men kulturhistorisk interessant er det derimod, at nogle af portrætterne desuden er arrangeret med forklarende draperi eller kulisse. Når Jessen således i 1797 har malet et portræt af borgmester Johan Frederik Carøe, Randers, så er det egentlige portræt ikke det interessante for tilskueren i dag. Meget morsommere er det at bemærke, at borgmesteren står på en loggialignende opbygning, hvorfra der er udsigt over mundingen af Randers fjord, hvor man ser herregården Udbyhøj og på vandet en hestedrevet opmudringsmaskine. På land $i$ forgrunden en hjulplov - Den nederste del af lærredet er illusionistisk bemalet, som var det brystværnet på en balkon med en påsat plakette, hvorpå der står:

"Johan Friedrich Carøe

Ved hvis Virksomhed som sin Fødebys Øvrighed i 28 Aar

Staden forskiønnedes, dens Handel og Næringsveje udvidedes

dens Indtægter, Politie og Fattigvæsen forbedredes,

Thi sattes hans Billede her af erkientlige Borgere«.

Portræettet hæenger endnu $\mathrm{i}$ rådhuset $\mathrm{i}$ Randers.

Hanne Poulsen skriver helt klart: » Jes Jessens portrætter er $i$ henseende til kunstnerisk værdi kun middelmådige, men deres kulturhistoriske værd er overordentlig stor «. Sin mest selvstændige indsats ydede Jes Jessen ved sine blomsterbilleder på træ, på møbler og panelværk. Ingen anden håndværker $\mathrm{i}$ hverken kongeriget eller hertugdømmerne har på »bondemøbler « malet blomster, der kunstnerisk står på højde med de bedste af Jessens brogede buketter på sort bund. Se f. eks. skabet eller alkovedørene i »Løjtstuen « på museet i Åbenrå, eller endnu bedre de skønne kirkestolestader, som også er at se på museet. - Denne dekoration og staffering af møbler og stuer er jo iøvrigt noget ganske særligt for Sønderjylland $\mathrm{i}$ det 18. århundrede. Hanne Poulsen har stort kendskab og kxrlighed til denne kunstepoke, og en hel del af hendes bogs læsere vil nok få det.

Harry Jensen

\section{Peter Beck: Dansk dreng I Sundeved.}

Udgivet af Historisk Samfund for Sønderjylland 1974. 166 sider, ill.

Selv mod visse sprogrenseres protest skal det siges, at der i sproglig henseende er en nuance af forskel i tydningen af ordene »minder « og 
»erindring «. Minder er ifølge den store danske ordbog en "genfremstilling af forestillinger i omdømmet «, et udtryk, som vil være fuldt ud gxldende ved vurderingen af fhv. lektor Peter Becks bog om oplevelser og indtryk fra hans sundevedske hjemegn. Men denne bog er tillige præget af, hvad den flittigt erindrende Søren Kierkegaard har kaldt erindringens lykkelige kærlighed. Dermed er der i dobbelt forstand sagt noget afgørende om bogens indhold og kvalitet.

Det er en lykkelig kærlighed, der bxrer lektor Becks skildring af hjemstavnen, af fødegården og dens omgivelser, de stynede elmetræer, markernes levende hegn og haven med dens blomster. Dens tyske navn "Junkershof " stammer fra den som bondeplager kendte glücksborgske hertug Philips storgods med slottet "Philipsborg", der forlængst er forsvundet, men dets historie er der blevet plads til i den lille bogs rige indhold. Det drejer sig først om det daglige liv, således som det formede sig på en sundevedsk bondegård, et levende kulturbillede fra årene omkring århundredskiftet, som hos mange vil kalde både på minder og erindringer.

Dertil hører også skildringen af årets gang og de forskellige gøremål inde og ude, familieforhold og højtider, alt inden for dette landsby- og sognesamfund og dets funktioner omkring den gamle kirke. Den ene af kirkeklokkerne skal være skyllet $i$ land på Nordstrand efter stormfloden 1634 fra en by, der forsvandt $i$ havet. Herom har »de gamle « fortalt sagn, og de har fortalt mange andre ting, bl. a. om Frederik den Syvendes færd under udgravningen ved Nydam mose, da han af en gammel småkårskone bramfrit blev tiltalt "hæ' kong" og anmodet om (efter en håndvask) ikke at tørre sine hænder midt på et rent håndklæde.

Lxseren bliver præsenteret for et helt persongalleri fra datiden, nogle betydende og særprægede, blandt dem den stærkt nationalsindede Johan Andresen, der ikke undså sig ved at affærdige en tysk lærer, der ønskede at beholde sit embede efter genforeningen, med et »Do hæ wæt en skit karl olle daw! « Man må have levet et jævnt og muntert liv i Ullerup, men $i$ øvrigt $i$ et godt fallesskab. En pengeflod, som den vi svømmer $i$ for tiden med hushøje priser, kendte man ikke til. Bager Lassen solgte sine rundstykker for 2 penning stykket

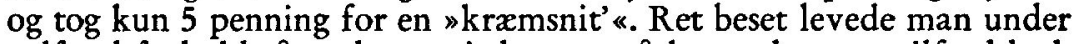
velfærdsforhold så godt som $\mathrm{i}$ dag og måske med større tilfredshed.

Naturligvis havde sognet (Ullerup) også sine originaler. En af dem var Anders Bartram, fotograf, billedskxrer, astronom og arbejdsmand. Det sidste egnede den i øvrigt meget kyndige mand sig dog ikke til, men i sin hjemmelavede kikkert kunne han observere skrammerne på Sottrup kirkeurs viser. Han kunne godt under andre forhold være blevet til noget stort. Den fornøjelige malermester Chr.

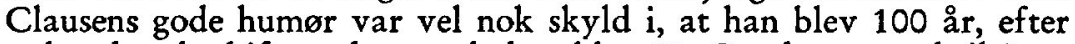
at han havde skiftet erhverv, da han blev 80. Og al ære værd til Jørn 
Jessen, der ved at lave træsko havde kunnet lægge så meget til side, at han kunne hjolpe sin søn til en lille gård.

Et afsnit er helliget sognets tidligere præster, forst N. L. Feilberg, der blev afskediget 1864, dernæst efter den tid de tyske præster, der ikke var helt almindelige, men omtales med en vis respekt. Eichbaum Wilhelm Lange var dr. phil. og skomagersøn fra Åbenrå. Han var slesvig-holstener, og ved hans ankomst til Ullerup blev han omtalt $i$ en vise, hvis første strofer lød: "En skomagerdreng fra Affenrå med sine lange støvler på «. Pastor G. Jebsen var tysk, men den unge Peter Beck kom til at stå $i$ et venskabeligt forhold til ham og hans frue, efter at hun vederlagsfrit havde tilbudt at undervise ham i fransk og andre fag, før han blev optaget som elev på det tyske gymnasium $i$ Sønderborg. Første gang han hørte pastor M. Th. Mahler, forskrækkedes han af den tordenstemme, med hvilken den kendte vækkelsesprædikant ved lejlighed fordømte folk, som kørte korn ind om søndagen. Det fik den gamle, kloge hjulmager P. Jessen til at gøre opmærksom på, at Jesus helbredede syge om søndagen.

Spændingen mellem dansk og tysk var konstant, men dog ikke mere udpræget, end at den tyske gendarm gik og fløjtede melodier til danske fædrelandssange. Det passede ikke hans kone, men hun aff $æ r-$ diges med et "Wieso, ich höre ja nicht anders «. Når han under den første verdenskrig bragte et sorgens budskab til danske hjem, mødte han i civil. For øvrigt lod det til at more pastor Jebsen lidt, når han lagde mærke til, at man på mandssiden $\mathrm{i}$ kirken "pillede lidt ved flippen «, medens han bad for kejseren. Et kapitel handler om krigsårene, som ramte sognet med 72 faldne, og om de særlige vanskeligheder, de førte med sig.

Det er forståeligt, at lektor Beck som skolemand med særlig interesse fortæller om skoleforholdene, om lærere, blandt hvilke han nævner fru pastor Jebsen som en af de bedste, han har haft, og om skolekammerater. Han var, selv om degnen talte bedre sønderjysk end tysk, glad for undervisningen i Ullerup skole. Personlig kom han under overgangen fra tysk til dansk $\mathrm{i}$ tiden for 1920 ud for ikke helt almindelige omskiftelser. Han blev elev i fire gymnasier, først i de tyske gymnasier i Sønderborg og Flensborg, så på latinskolen i Kolding, for så til sidst at afslutte på det nye danske gymnasium i Sønderborg. Hans skildring af de forskellige undervisningsformer og $1 \mathfrak{x}$ rernes personligheder er blevet et interessant skolehistorisk kapitel.

Lektor Beck har ikke villet skrive en sognehistorie, men han har givet et betydningsfuldt bidrag til en sådan, og mere end det. Hans oplevelser og vurderende omtale omfatter de første 20 år af vort århundrede. Det er blevet en fremstilling, som nyder godt af hans glimrende fortælleevne. Minder melder sig, erindringer nedfæxldes. 


\section{Morten Kamphövener: Borgerskaber I Ábenrå 1686-1867.}

Udgivet af Åbenrå byhistoriske Forening, Landsarkivet for de sonderjyske Landsdele og Historisk Samfund for Sønderjylland. Åbenrå 1974, bind I 235 sider og bind II Registre, 92 sider (stencileret).

Med den stadig voksende interesse for personalhistorien har der vist sig muligheder for at få de ikke alene for byernes historie, men også for personalhistorien så værdifulde borgerskabsprotokoller udsendt på tryk. Således udkom i 1928 i årbogen Fra Ribe Amt V. Blochs og Otto Schmidts Ribe Borgere 1660 - ca. 1860, i 1937 forelå Tønderhistorikeren Ludwig Andresens Bürger- und Einwohnerbuch der Stadt Tondern bis 1869, og i 1940 Thomas Otto Achelis' Bürgerbuch der Stadt Hadersleben bis zum Jahre 1864 og endelig i 1955 Otto von Spreckelsens Viborg Bys Borgerbog 1713-1860.

$\mathrm{Nu}$ har Ảbenrå by også fået sin borgerbog udsendt på tryk, idet redaktør Morten Kamphövener, der i sin fritid har været en ivrig og flittig lokal- og personalhistoriker, ved sin pensionering trods sin høje alder påtog sig det brydsomme hverv at medvirke ved udgivelsen af Åbenrå borgerskabsprotokoller. De er bevarede fra 1723-1777 og fra 1791-1882, men hertil kommer en del løse borgerbreve og andre kilder fra 1686-1867.

Lykkeligvis nøjedes Morten Kamphövener ikke med det mere enkle arbejde at lade protokollernes sparsomme oplysninger om tidspunktet for borgerskabets tildeling og om fødested og erhverv stå alene, men han fulgte i nogen grad eksemplet fra von Spreckelsens bog, som kompletterede materialet med personalhistoriske oplysninger fra andre kilder. Det var planen, at de supplerende oplysninger så vidt muligt skulle omfatte borgernes fødselsdata og fødested, forældrenes navne, vielse, hustruens navn og data og hustruens forældre samt såvel borgerens som hustruens dødsdata.

Det er klart, at alle disse oplysninger ikke har kunnet fremskaffes for alle borgernes vedkommende, dels er kildestoffet for mangelfuldt, og dels har der været for mange ukendte faktorer, så man ikke har kunnet finde de pågxldende personer $\mathrm{i}$ andre kilder. Det er glæedeligt at kunne konstatere, at dette store og krævende arbejde helt eller delvis er lykkedes $i$ langt over halvdelen af tilfældene, således at bogen vil være en guldgrube for interesserede, der har slægtsforbindelser til Åbenrå.

Bogen bringer $\mathrm{i}$ sit første bind en kronologisk oversigt over alle personer, der vides at have fået borgerskab i Åbenrå, og den tæller omkring 2800 navne. Til sammenligning tjener, at Tonder-bogen rummer godt og vel det samme antal, nemlig 2965 personer, medens Haderslev-bogen omhandler 3698 personer. Da denne bog imidlertid er en torso, idet der efter bogens trykning dukkede yderligere borgerskabsprotokoller frem, ligesom en række borgere var overset $i$ andre 
kilder, må der tillægges flere hundrede personer, hvoraf 207 fra den tidligere Slotsgrund, som i 1834 sammenlagdes med Haderslev kobstad, således at antallet af Haderslev-borgere bliver på langt over 4000 .

Bind 2 rummer et udførligt navneregister, der fylder 81 sider, hvortil kommer et register, som på 9 sider efter erhverv opdeler borgerne i 14 hovedgrupper. Dette register fortæller ikke alene, at Åbenrå har været en betydelig søfartsby, idet søfartens erhverv alene tegner sig for over 300 personer, men at byen efter forholdene også har haft et stort antal borgere, der drev handel. Derimod savnes desværre et stedregister, som ville have været af stor interesse, ikke mindst da det drejer sig om en by $\mathrm{i}$ grænselandet. Et sådant register ville blandt andet kunne have fortalt os, hvor mange borgere der var fra dansk- eller tysktalende egne, således som det er tilfældet med borgerbegerne fra Tønder og Haderslev. Her giver ikke mindst disse afsnit bøgerne en betydelig almindelig historisk interesse.

$\mathrm{Da}$ bogens hovedopgave, som arbejdet har været tilrettelagt, imidlertid har været at yde et bidrag til personalhistorien, skal denne udeladelse ikke bebrejdes forfatteren, men der kan være grund til over for udgiverne at pege på den og et par småmangler, som burde have været undgået. Der savnes en liste over forkortelserne, som ikke altid umiddelbart kan tydes, ligesom der måske burde have været oplyst lidt mere om principperne ved manuskriptets udformning. Der kan sommetider opstå tviul om føde-, døds- og vielsesstedet, idet der $\mathrm{i}$ mange tilf elde intet er anført herom, selvom der må være tale om Ả benrå, medens man lige så of te anfører $\AA$ Ả .

I titlen hedder det lidt pretentiøst fra 1686, men da der kun er én borger fra dette år, to fra 1695 og én fra 1699, burde titlen måske have været Borgerskaber i Åbenrå (1686) 1700-1867. Disse småting xndrer imidlertid intet $\mathrm{i}$ værdien af dette store og omhyggelige arbejde, som Morten Kamphövener har udført, og som med taknemmelighed vil blive hilst velkommen af personalhistorikerne. Bogen har fortjent at få sin plads på alle sønderjyske biblioteker og lokalhistoriske arkiver, ligesom den $\mathrm{i}$ det øvrige land $\mathrm{i}$ alt fald bør findes på alle større biblioteker, så den kan lette de mange personalhistorikere $\mathrm{i}$ et of te brydsomt arbejde.

Olav Christensen 


\section{Bognyt}

\section{Kurt Hector: Das Schleswig-Holstelnische Landesarchiv.}

Slesvig 1973. 58 s., ill.

Det slesvig-holstenske landsarkivs direktør gennem mange år, Kurt Hector, har med dette smukke og velillustrerede lille skrift tilvejebragt en nyttig og letlæselig introduktion til arkivets indhold og funktion. Hensigten er at præsentere arkivet både over for interesserede forskere og over for den administration, hvis arkiver afleveres dertil. Også for nordslesvigske lokalhistorikere er denne lille bog nyttig ved at gøre opmærksom på de mange muligheder, som det slesvig-holstenske landsarkiv åbner også for udforskningen af nordslesvigsk historie.

Det betones kraftigt $\mathrm{i}$ bogen, at landsarkivets placering fra 1948 på Gottorp slot må betragtes som midlertidig. Fra et arkivalsk synspunkt er lokalerne på Gottorp nemlig alt for små og til dels sikkerhedsmæssigt uforsvarlige. Fra forskningens og administrationens synspunkt vil en placering i Kiel nær universitet og landsadministration være at foretrække, og man må derfor håbe for arkivet, at dets ønske om at få tidssvarende bygninger i Kiel snart kan blive realiseret. Fra nordslesvigsk side vil der næppe være noget at indvende herimod $\mathrm{i}$ betragtning af de gode låneforbindelser, der eksisterer mellem landsarkivet i Ảbenrå og det slesvigholstenske landsarkiv.

D. A.

Hans H. Worsøe: Slægtshistorle. Dansk Hlstorlsk Fællesforenings håndbøger. 1973. 103 s., ill.

I 1962 udsendte arkivar Worsøe den lille Grundbog i Slægtshistorie, der efterhånden er kommet $\mathrm{i}$ fem oplag. Denne bog er en ny, revideret og udvidet udgave heraf. Hermed er der tilvejebragt et hjxelpemiddel, der vil være uundværligt både for begynderen og den viderekomne slægtsforsker, og det må derfor anbefales enhver, der påtænker at begynde at forske $i$ sin slægt, at sætte sig grundigt ind $\mathrm{i}$ denne bog, før arkivstudierne påbegyndes. $\mathrm{På}$ den begrænsede plads har det også været muligt for forfatteren at tage hensyn til de specielle sønderjyske forhold; men for udførligere besked 
herom må man naturligvis stadig henvise til Worsøes egen reviderede udgave af Johan Hvidtfeldt: Slægtshistoriske studier i Sønderjylland fra 1965.

D. A.

\section{Hedekolonierne.}

Udgivet af Landsarkivet for Nørrejylland ved Poul Rasmussen med sagregister og oversigter udarbejdet af Niels Windfeld Lund. Viborg 1974. $93 \mathrm{s.}$

I den stadig mere rivende strøm af udgivelser af vejledende arkivregistraturer er der særlig grund til at standse op ved denne om de nørrejyske hedekolonier. Den indeholder en detaljeret oversigt over alt landsarkivets og rigsarkivets materiale vedrørende hedekolonierne; men det, der gør registraturen særlig anvendelig for forskeren, er det udførlige sagregister, den er forsynet med. Registret er blevet til ved en indholdsregistrering af hvert aktstykke for sig, og herved er denne kildegruppe i usæedvanlig grad blevet åbnet for forskningen. Arkivvæsenets stadig knappere ressourcer giver normalt ikke mulighed for udarbejdelse af så udforlige hjxelpemidler, og sagregistret er da også blevet til på grundlag af forarbejder, udarbejdet af stud. mag. Niels Windfeld Lund, der også har leveret oversigten over arkivalier i rigsarkivet. Publikationens forord gør med rette opmærksom på de perspektiver, der ligger $i$ et sådant samarbejde mellem arkiv og forsker, med henblik på det fremtidige arbejde med at gøre arkivalier lettere tilgængelige for deres benyttere.

D. A.

\section{Jørgen Køster: Gárden fra Sønder Sejerslev.}

Nationalmuseet. 1973. 40 s., ill.

Da Frilandsmuseet ved Sorgenfri i august 1971 kunne indvi Søren Mikkelsen Clausens gård fra Sdr. Sejerslev nord for Højer, kunne man glæde sig over to ting.

For det forste havde Nationalmuseet med nyerhvervelsen og overførslen til parken ved København fået sit hidtil største bygningsværk på Frilandsmuseet under tag. For det andet var byggeskikken i den sydvestlige del af det danske monarki nu fuldgyldigt representeret. Allerede i 1960 havde man fåt gården Rothelau fra den sydslesvigske halvø Ejdersted, opført på værft, som type på en egentlig marskgård, og nu fulgte så en statelig landbrugsejendom fra egnen på kanten mellem geest og marsk.

Det sidste er, at Sdr. Sejerslev-gården har fået sin bog med beskrivelse, fotos og tegninger. Forfatteren er folkelivsforskeren Jørgen Koster, der gennemgår gårdens historie og udvikling fra 1600-tallet og fremefter. Ejeren kan føres tilbage til 1600-tallets slutning. Det var en Tyge Hansen, om 
hvem man véd, at han drev studehandel og endvidere har haft interesser i skibsfarten i Vadehavet. Den næste ejer var Peter Michelsen, som lavede smukke standure, og i 1874 kom der en Claus Nielsen Clausen til. Han var en fremskridtsmand, der straks købte en slåmaskine for at spare penge til høstfolk. Udvandringen, der fulgte $\mathrm{i}$ kølvandet på den prøjsiske erobring, kom nemlig til at betyde mangel på arbejdskraft og stigende lønninger.

Claus Clausen hørte til sognets overklasse, idet familien ejede flere gårde. Faderen, Mikkel Sørensen Clausen, blev fulgt til graven ved Emmerlev kirke af ca. 270 personer med 68 vogne. På gården bespistes 200 gæster, antagelig efter egnens skik med vinsuppe og kogt skinke med stu. vede kartofler.

Bogen gør det næsten ud for et museumsbesøg; men selve bekendtskabet med den kønne gård og dens antikviteter inden døre har man til gode.

E. B.

\section{S. Tougaard og H. Meesenburg: Den Jyske vestkyst. En geografisk fortælling I flyfoto og kort.}

Udgivet ved Fiskeri- og Søfartsmuseet, Esbjerg. Bygd 1974. 45 dobbeltsider.

Det er en imponerende bogproduktion, der knytter sig til Fiskeri- og Sofartsmuseet $i$ Esbjerg. Ind $i$ rækken af væsentlige og $i$ god forstand populare udgivelser kommer nu denne bog, der er bygget op over flyfotos, optaget i 1973-74. Billederne modstilles historiske og aktuelle kortudsnit, og på hver kortside findes en kommenterende tekst, tydeligvis skrevet af geografen, men netop derfor spændende for den, der er vant til at betragte tingene fra et historisk aspekt. Materialet strækker sig fra Ringkøbing fjord i nord til den nordlige del af Sild. Halvdelen af det hidrører fra det sønderjyske område. De mange, der færdes herude, som beboere eller turister, vil have umiddelbar glæde af at se »det hele sådan lidt fra oven «; men man skal give sig tid til at læse teksterne. Det er en dybtgående viden, der står bag disse.

K. F.

\section{H. V. Gregersen: Messe og marked. Fra det gamle Kliplev sogn og Søgård gods.}

Folkeligt forlag. Haderslev 1974. 149 s., ill.

H. V. Gregersen: "Messe og marked. Det landskendte Kliplev marked « kom i 1955. Det er glædeligt vidnesbyrd om den lokalhistoriske interesse, at bogen nu har kunnet komme $i$ anden udgave. Der er foretaget enkelte tilføjelser $\mathrm{i}$ teksten, og noterne er blevet noget fyldigere. Den væsentligste xndring er dog, at bogen er blevet illustreret. Omslaget virker i sin gen- 
givelse af et udsnit af Johannes Mejers kort fra 1650 meget smukt. Forfatteren har kunnet glæde sig over støtte til udgivelsen fra to så forskelligartede sider som Den grevelige Hielmstierne-Rosencroneske Stiftelse og Institutionen Kliplev Mrrken.

K. F.

\section{H. C. Davldsen: Forbryderalbum.}

Udgivet af Tonder Bibliotek. 1973. 61 s.

I anledning af sit 50-års jubilæum i oktober 1973 udsendte Tønder Bibliotek denne lille bog, der rummer tegninger af ialt 36 dansksindede personer fra Nord-og Mellemslesvig, tegnet under H. C. Davidsens og deres ufrivillige fangetilværelse i Flensborg august-september 1914 på Altes Gymnasium og siden Navigationsskolen. Originaltegningerne, der findes på Tønder Museum, er her for forste gang gengivet $i$ naturlig størrelse. Der findes på museet nogle enkelte flere end de gengivne, væsentligst af folk med viden om navigation fra Flensborg og fjordegnen. Man kunne have ønsket sig alle taget med.

Bogen rummer udover tegningerne P. Skovrøys muntre og bevagede beretning om opholdet i Flensborg, genoptrykt efter Sønderjydsk Centralforenings festskrift, 1923, der bragte Davidsens tegninger $\mathrm{i}$ formindsket udgave. Werner Christiansen skriver udførligt om godsinspektør H. C. Davidsen, Schackenborg, manden med de mange evner og interesser, og giver gode biografier af hver af de portrætterede, der alle på nær én, Hans Brink, Rørkær, der faldt på slagmarken, fik et virke i Nord- eller Sydslesvig efter 1920. Som indgangsvignet har bogen en gengivelse af mobiliseringsordren for Ortsbehörde i Tønder med notat fra borgmester Plewka om offentliggørelse. Den er fundet $i$ svigersønnen, overlæge Jens Lorenzens efterladte arkiv. Også et løsladelsesdokument offentliggøres her for første gang og er spxndende læsning.

Men naturligvis er det især gensynet med portrætterne, der interesserer; for dem af de portrxtterede, man har kendt, er realismen slående, f. eks. i billedet af Hans Lorenzen, Ballum. Enkelte af »ofrenex gjorde dog selv indvendinger. Det gjaldt Skovrøy, der hævdede, at han var blevet for gammel på billedet, og grev Schack, der mente, at næsen var blevet for stor. Men stort set har Davidsen her haft samme sikre hånd, som man kender fra hans tegninger af vestslesvigsk arkitektur.

$$
\text { K. F. }
$$

\section{Jens N. Lorenzen: Fra Tonder Slotsbanke.}

Tonder Museum 1974. 48 s., ill.

Med denne lille bog, der rummer otte af afdøde overlæge Jens $N$. Lorenzens historiske studier vedrørende slxgten og det gamle Tønder, har fru 
A. Lorenzen, der har bekoster udgivelsen, sat sin mand et smukt minde, hjulpet af Werner Christiansen og Sigurd Schoubye, der har redigeret bogen. Werner Christiansen skriver tillige om overlagen og dennes fader, gasmester Mathias Lorenzen. - På et tidspunkt, hvor der sker så meget på Slotsbanken i Tonder, er man taknemmelig for, at det er lykkedes at give stedets baggrund, fastholdt $\mathrm{i}$ disse skildringer fra "Udsigtsbænken ved Tønder gasværk $\ll$.

\section{K. F.}

\section{Valsbel danske menighed 1923-1973.}

Valsbel 1973. 72 s. ill.

I anledning af 50-års jubilæet $\mathrm{i}$ november 1973 udgav Valsbøl danske menighed med pastor M. Salomonsen som redaktor et $\mathrm{i}$ det ydre nydeligt festskrift med tegninger af Leif Dahl og Guttorm Petersen og en række udvalgte fotos, der illustrerer menighedens liv. Det er blevet et skrift, der fortæller om denne særlige menighed, men også rummer et betydeligt kildestof til belysning af forholdene $i$ et mellemslesvigsk sogn i tiden fra 1920 til nu. Der er sygeplejersker og medlemmer af menigheden, der kan fortælle, der er præster fra Nordslesvig og med tjeneste andetsteds i Sydslesvig, der fortzller om deres møde med Valsbøl. Hovedbidragene bliver Hans Kvists og Martin Salomonsens. De beretter sammen med N. P. Nielsen og Kr. Svendsen foruden om eget virke om Maren Sørensen, hvis personlighed og indsats var afgørende for livet $\mathrm{i}$ Valsbøl og *Valsbølhus «. Også hendes trofaste hjxlper Kathrine Bøjlesen făr sin fortjente plads i skildringerne. Pastor Jordt Jorgensen fortæller om de $1 \frac{1 / 2}{2}$ ar, han boede på »Valsbølhus«, efter at hans bolig i Flensborg var bombet, og skolelederne Johs. Fink og Ebbe Vestergaard giver deres indtryk af livet derude.

Lune og munterhed, alvor og tragedie rummer disse skildringer. Et referat skal ikke forsøges her. Det er blevet en meget væsentlig bog, der, hvis senere generationer interesserer sig for deres fortid, kan få samme værdi for dem som H. F. Feilberg: "Fra Heden « har for os som kildeskrift idag. Den kan endnu fås hos redaktøren, pastor M. Salomonsen, Valsbøl (10 DM eller $25 \mathrm{kr}$.).

K. F.

Ole Bjørn Kraft: Frem mod nye tider. En konservativ politikers erindringer $1945-47$.

Gyldendal 1974. 206 s., ill.

Ole Bjørn Kraft, der $\mathrm{i}$ sine tidligere erindringsbind har berettet om sin stillingtagen til grænsespørgsmålet 1918-20 og om sit virke som journalist 
i Nordslesvig, er med dette bind af sine erindringer nået frem til et stærkt bevæget afsnit $\mathrm{i}$ dansk politisk historie, hvor han indtog en central placering. Når dette binds fremkomst skal noteres her, skyldes det dog især, at Sydslesvigpolitikken $\mathrm{i}$ Knud Kristensens regeringstid og vurdering af den optager en meget stor part af bogen. Ole Bjørn Kraft har som daværende medlem af det udenrigspolitiske nævn haft adgang til nævnets protokoller og bygger desuden sin fremstilling på personlige notater. Kraft beretter tillige om sit arbejde som Det konservative Folkepartis ordfører i Sydslesvigpolitikken. Forholdet til Christmas Møller og hans politik belyses indgående, og man læser med interesse Krafts vurdering af årsagerne til Christmas Møllers brud med partiet og redegørelsen for hans personlige forhold til Christmas Møller. Bogen giver ikke væsentligt nyt vedrørende selve Sydslesvigspørgsmålet, men en lang række oplysninger om den interne stillingtagen $\mathrm{i}$ partiet.

K.F. 


\section{Noter og nyt}

\section{Kontorist Chr. Thomsen}

Historisk Samfunds gode medarbejder, kontorist Chr. Thomsen, Rødekro døde pludseligt og uventet natten mellem d. 23. og 24. juli $i$ en alder af kun 57 år. Han var født i Bodum, Løjt sogn, hvor han overtog fædrenegården; men på grund af et svagt helbred måtte han tidligt opgive det fysisk belastende landbrugsarbejde, og han ansattes derefter 1965 som Historisk Samfunds medarbejder, hvor hans uddannelse som kontrolassistent kom ham til gode. Hans arbejdsfelt spxndte vidt. Han medvirkede

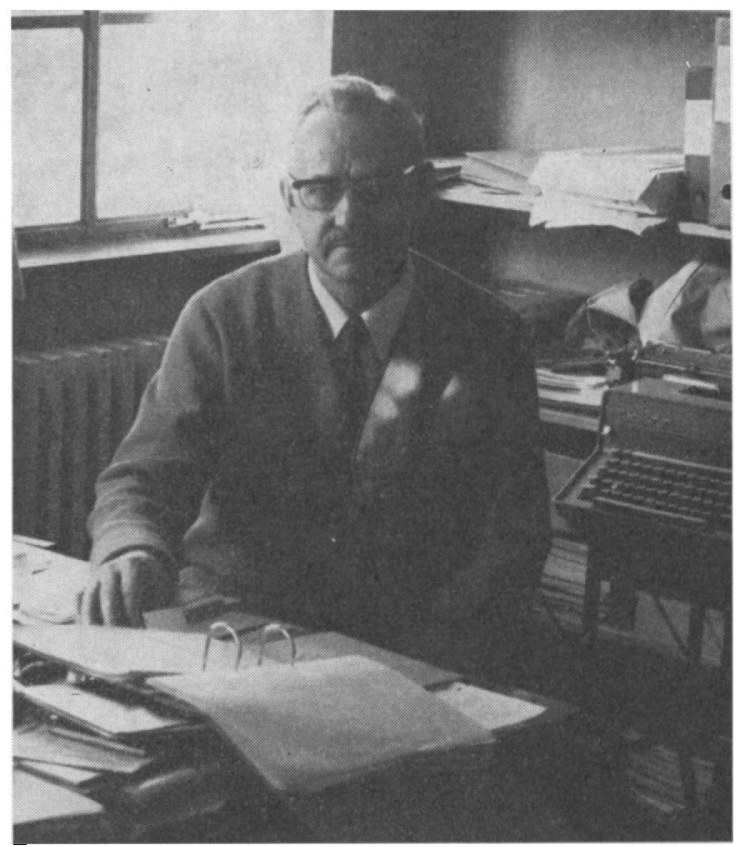

Chr. Thomsen (1917-1974). 
ved renskrivningsarbejde, ved ekspeditionen af bøger, men først og fremmest førte han momsregnskabet og sørgede for ajourføringen af Sønderjysk Månedsskrifts abonnentskartotek. Hans udprægede ordenssans var ham en god hjxlp her. Mange medlemmer har mødt ham på møder og udflugter eller på kontoret, og i alle situationer var han trods sin sygdom, som han tappert stred imod, foreningens flittige, venlige og imødekommende medarbejder. Som sådan vil han blive husket og mindet.

Peter Kr. Iversen

\section{Landsarkivet, Abenrå Byggeriet afsluttes}

Det kan vel altid diskuteres, om året 1973 eller 1974 er det vigtigste i landsarkivets historie. Nybygningen toges $\mathrm{i}$ brug 1973, og i begyndelsen af 1974 afsluttedes ombygningen af den gamle bygning, således at den officielle indvielse af hele komplekset kunne finde sted d. 1. april 1974. I hvert fald er begge år meget betydningsfulde, såvel for landsarkivets besøgende som for dets personale.

Ombygningen af den gamle arkivbygning påbegyndtes d. 1. maj 1973, og der blev i stueetagen mod syd indrettet garderobe og toiletter for landsarkivets gxster. For disse er det også en nyhed, at der til brug for dem i garderoben er placeret aflåselige taskebokse. I sydgavlen er der endvidere strbt en trappe, der fører op til magasinerne på 1. og 2. sal. Stueetagens magasin er helt forsvundet. I stedet for er der her indrettet kontorer og arbejdsrum for Historisk Samfund for Sønderjylland og Historiske Samlinger for Sønderjylland. Der er et arkivrum med plads til ca. 5000 lydbånd, der er afspilningsrum for disse, og der er et arkivrum beregnet for fotografisk materiale. Ialt kan der vel vxre plads til et par hundredtusinder billeder og negativer. Historisk Samfunds betydelige klichesamling opbevares også her. Der er også fotografisk atelier og mørkekammer, men foreløbig har det på grund af personalemangel ikke været muligt at tage disse sidstnævnte lokaler $\mathrm{i}$ brug. I nordgavlen er trappen flyttet ud til den gamle hovedindgangsdor, og midt i den gamle læsesal er der nu placeret en elevator. Der findes også her et depotrum for rengøringsassistenten. Kontorerne på første sal er helt ombygget. De er møbleret, men bliver på grund af statens personalestop vel nxppe foreløbig taget $\mathrm{i}$ brug. I sydgavlen er der på 1. sal indrettet kortrum. Der er her langs væggene placeret store stålskabe med flade skuffer, hvor kort og pergamenter kan anbringes. I sydgavlen på 2. sal er der indrettet lagerrum for Historisk Samfunds betydelige beholdning af ældre og nyere skrifter. Indflytningen $i$ lokalerne i den gamle bygning fandt sted i januar måned, men da enkelte småtterier bl. a. på grund af leveringsvanskeligheder ikke kunne forventes afsluttet før omkring 1. marts, måtte indvielsesfesten udskydes til 1. april, hvilken dag kulturminister Nathalie Lind kunne være tilstede. 


\section{Indvielsen}

Indbefattet landsarkivets personale var op imod 140 personer forsamlet d. 1. april $\mathrm{i}$ den nye kombinerede foredrags- og udstillingssal, da lærer $\mathrm{C}$. Jensens folkemusikensemble kl. 9.30 intonerede med en potpourri over sønderjyske sange. Efter en fællessang bød byggeudvalgets formand, stiftamtmand C. A. Vagn-Hansen, derefter $i$ en formfuldendt tale velkommen til kulturministeren, ministeriets embedsmænd, de udenlandske gaster, rigsarkivar Mannsåker fra Norge og Landesarchivdirektor W. Prange fra Gottorp og til reprasentanter for de lokale kommunale råd og embeder med amtsborgmester Erik Jessen i spidsen. I sin tale rettede stiftamtmanden en tak til håndværkere, arkitekter og ingeniører og understregede, at ikke blot var tidsplanen overholdt, men at det også var lykkedes at gennemføre byggeriet uden overskridelser. Det var et eksempel til efterfølgelse. Han overdrog derefter bygningen til kulturministeren med bemærkningen om, at hun nok ville forstå at holde justits med den og dens indhold.

I sin tale sagde kulturministeren bl. a.: Det er mit håb for landsdelen og landsarkivet, at dets magasiner og reoler ikke kun skal rumme minder om, hvor fædrene har kæmpet og mødrene har grædt, men også danne rammen om fremtidens samarbejde mellem folkene $\mathrm{i}$ grænselandet, og at de mennesker, der lever her, vil hente inspiration i de historiske kilder, ikke til at ruste sig til kamp, men til at dygtiggøre sig til samarbejdets krav, og at landsarkivet vil blive ikke blot et mindesmarke over fortidens strid, men vil komme til at bxre vidnesbyrd også om nutidens og fremtidens indsats. Ministeren lykønskede grænselandet og det danske arkivvæsen med det større ny landsarkiv og overdrog dermed bygningen til rigsarkivaren. Inden han tog ordet, spillede C. Jensens ensemble en potpourri over sønderjyske folkemelodier.

Rigsarkivar, dr. phil. Johan Hvidtfeldt fremdrog i sin tale personlige minder fra sin tid som arkivar ved landsarkivet og mindedes det gode samarbejde med landsarkivar Frode Gribsvad og arkivbetjent Jeppe Juhl. Han takkede arkitekt og teknikere, der har taget alle hensyn til arkivvæxsenets onsker om sikkerhed for arkivalierne, der er et fint funktionelt samspil mellem lesesal og magasiner, og der er skabt gode forhold for medarbejderne. Han fortsatte: "Landsarkivet har også fået en magasinkapacitet, som må anses for tilfredsstillende. Dette er så meget mere vigtigt, som der ikke kan være tvivl om, at den stærke udvikling af den kommunale forvaltning gennem kommunalreformen i 1970 og senere lovgivning har betydet, at landsarkivernes materiale $i$ årene fremover vil få forholdsvis storre betydning - sammenlignet med den centrale forvaltnings arkiver. Denne udvikling har vel også betydet en foregelse $i$ det, man kan kalde papirproduktionen, og det giver os betænkeligheder. Arkivfolk ønsker $\mathrm{i}$ virkeligheden så lidt administration og dermed så få arkivalier som muligt. Vi kan nok være glubske, når det gælder papir, men vi kan også blive mætte, og forvaltningen skal i hvert falk ikke skabe papir for vores skyld hvad jeg heller ikke mistanker den for «. Han sluttede med at overdrage 
nybygningen til landsarkivets personale, idet han udtalte onsket om, at arkivet ville få stadig voksende betydning for historisk og kulturelt arbejde i Sønderjylland $\mathrm{i}$ årene fremover.

Landsarkivar Peter Kr. Iversen gav udtryk for glæde og taknemmelighed og takkede folketing og kulturministeriet, som havde stillet sig så positivt ved gennemførelsen af byggesagen. Endvidere rettedes en dybfølt tak til rigsarkivaren, der havde givet byggesagen her første prioritet frem for andre omtrent lige så påtrængende byggesager inden for arkivsektoren. Han omtalte også det gode samarbejde med byggeudvalg og med teknikerne. »Der er $\mathrm{i}$ bygningen skabt de bedste muligheder for den historiske forskning $i$ alle dens afskygninger. Der er skrevet disputatser og andre videnskabelige afhandlinger pà grundlag af materiale $i$ dette arkiv, og det vil forhåbentligt også ske fremover. Men den største berøringsflade har landsarkivet haft med de mange lokal- og personalhistorikere, som år efter år er kommet til os og har måttet arbejde under alt for trange forhold $\mathrm{i}$ den gamle læesesal. Det skal da også siges helt klart ved denne lejlighed, at det lokalhistoriske, det personalhistoriske - hele det folkeligt historiske arbejde vil blive prioriteret hejt. Der er nu skabt muligheder for afholdelse af kurser, foredrag, møder og udstillinger, og vi håber, at mange vil gøre brug af disse nye lokaler og de moderne faciliteter, som de er udstyret med. Dette landsarkiv er det forste, hvor kontakten til det folkelige historiske arbejde har givet sig virkeligt kontante udslag. Der har, så længe det sønderjyske landsarkiv har eksisteret, været samarbejdet med Historisk Samfund for Sønderjylland, og i de senere år har denne forening, om end under trange forhold haft sekretariat og ekspedition her. Nu har ikke blot Historisk Samfund fået god plads til sine aktiviteter, men også Historiske Samlinger for Sonderjylland, der er et barn af Historisk Samfund, har fået lokaler til opbevaring af billed- og båndsamlinger og til medarbejderne. ... Dette hus skulle gerne kunne fungere som en slags åndelig rasteplads til stille fordybelse i studiet af slægtens spor i stort og småt. Der skal her være plads for såvel den fagligt skolede forsker som til den almindelige historisk interesserede besøgende, der søger oplysning om sin slægt og sin hjemstavn. Det skal være et hus, der bruges af brede befolkningslag, og det skulle gerne blive et betydningsfuldt led i denne landsdels folkelige arbejde og trivsel«.

Der vistes derefter en farvefilm optaget under byggearbejdet af ekspeditionssekretær Preben Jakobsen, og den mere officielle del af indvielseshøjtideligheden afsluttedes med Jeppe Aakjærs sang: Som dybest brønd.

Landsarkivar Peter Kr. Iversen forklarede derefter ved hjxelp af plancher nybygningens indretning, hvorefter gasterne delt $\mathrm{i}$ tre hold beså bygningen under ledelse af arkivarerne Dorrit Andersen og Jørgen Witte samt landsarkivar Peter Kr. Iversen. Efter disse anstrengelser var der let servering i læsesal, foyer og tilstødende mødelokale. Et højttaleranlæg sikrede, at alle kunne høre de mange gaster, der overbragte lykønskninger.

Amtsborgmester Erik Jessen betragtede arkivet som hele landets gave til 
Sønderjylland og takkede de skiftende regeringer for det. Historisk Samfund for Sønderjylland forærede ved sin næstformand, Chr. Stenz, landsarkivet 70 eksemplarer af højskolesangbogen, idet han takkede for godt samarbejde mellem foreningen og landsarkivet. Den norske rigsarkivar Mannsåker gratulerede med bygningerne og overrakte en faksimileudgave af middelalderlige norske lovtekster. Arkitekt Schmidt Christensen overrakte på arkitekternes og ingeniørernes vegne en skulptur af billedhuggeren Erik Ālykke, og Ảbenrås borgmester, Camma Larsen-Ledet, forærede arkivet et fad prydet med byens gamle våben. Landesarchivdirektor, dr. Wolfgang Prange fra Gottorp holdt en elegant tale på dansk om forbindelsen mellem de danske og de slesvig-holstenske arkiver. Rektor Buchreitz, formanden for Ảbenrå byhistoriske Forening, lovede, at foreningens samling af fotografier og dokumenter ville blive overdraget landsarkivet som foreningens gave.

Afsluttende under frokosten talte socialinspektør Olav Christensen som lokal representant for Sammenslutningen af lokalhistoriske Arkiver og lxge $\mathrm{H}$. Roesdahl, formand for Historisk Samfund for Als og Sundeved, som også har nær kontakt til arkivet. Assistent H. A. Jacobsen takkede på landsarkivets personaleforenings vegne for de gode arbejdsforhold, som personalet havde fået $\mathrm{i}$ den nye bygning. Den $x$ ldste lresesalsbesøgende, fhv. redaktør Morten Kamphövener og landsarkivar, dr. phil. Harald Jørgensen var de sidste talere blandt gasterne. Ind mellem talerne blev der sunget med musikledsagelse af C. Jensens ensemble. Landsarkivar Peter Kr. Iversen sluttede festen med at takke for de mange gaver og hilsener, som arkivet havde modtaget $\mathrm{i}$ dagens anledning.

\section{Arbejdet}

Som det kunne forventes, måtte besøgstallet i kalenderåret 1973 falde, dels på grund af lukning af læsesalen $i$ over en måned, medens selve flytningen stod på, og dels på grund af rodet omkring flytningen. Besøgstallet på læsesalen var 1814 mod 2013 i 1972, der også havde vist vigende tal. Ekspeditionen til læsesalen, der 1972 var 16.626 bind, pakker og læg, var 1973 14.011; af indlån var der 197363 mod 39 foregående år, udlån til administrationen var 1972 8, 1973180 og udlån til andre 1972744 bd., pkr., stkr., 1973 342. Afleveringen fra embeder, der 1972 udgjorde 115 løbende hyldemeter, var 1973472 labende meter, medens tilvæksten ved gaver var henholdsvis 33 og 48 løbende hyldemeter. I 1972 kasseredes 18 lobende hyldemeter, medens tallet for 1973 var 20 meter. Et arbejde, der har været støt voksende $i$ de senere år, er indforelse af rettelser og tilføjelser i personregistrene. I 1972 var deres antal 546, i 1973 633. Konserveringsværkstedet toges $\mathrm{i}$ brug $\mathrm{i}$ midten af maj, og siden da er der konserveret 2 pergamenter, 2 segl, 9 protokoller og ca. 2300 blade. Der er indbundet 25 biblioteksbind og 27 arkivbind. 
Efter indvielsen er besøgstallet steget, og det er ikke helt ualmindeligt, at der nu samtidig kan være op imod en snes besøgende på læsesalen. Der kan derfor forventes betydeligt højere besøgstal for 1974. Vaksten i afleveringer 1973 hidrører især fra afleveringer fra de nedlagte amter og amtsråd. Blandt afleveringer af private personarkiver kan bl. a. nævnes skovejer N. L. Bossens arkiv (aflev. af landsretssagfører Svane, Padborg), købmand i Løgumkloster Anna Clausen Jensens arkiv (aflev. af Birgit Petersen, Skærbæk), gårdejer Laust Arnums dagbøger 1878-1907 (aflev. af fru E. M. Lund, Tanderupgård), supplement til Anders Lebecks arkiv (ved fru Anna Ølgaard), supplement til fru Else Floranders arkiv, supplement til Magdalene og Peder Moos' privatarkiver (ved forstander Johanne Moos, Nybol), supplement til pastor $\mathrm{H}$. Magles privatarkiv og supplement til landdagsmand H. D. Kloppenborg-Skrumsagers privatarkiv (ved fru A. M. Skau, Nygård). Af institutions- og foreningsarkiver har landsarkivet i 1973 bl. a. modtaget en supplerende aflevering til Sydslesvigsk Kultursamfunds arkiv (ved professor Lor. Rerup), A/S Plantningsselskabet Sønderjyllands og Skxrbxk Planteskoles arkiver (ved skovrider B. Lindskov Christiansen, Skærbxk), brandtaksations- og forsikringsprotokoller for Tønder og Haderslev branddirektorater under Kobstædernes alm. Brandforsikring, adskillige sygekassearkiver, Ladegårdskov Andelsmejeris arkiv, supplerende aflevering af Historisk Samfund for Sønderjyllands og af Ảbenrå Svaneapoteks arkiver. Endvidere har Landsarkivet især ved Dansk Centralbibliotek for Sydslesvigs mellemkomst fået mulighed for at xeroxkopiere forskellige slægtsbøger, memoirer $\mathrm{m}$. $\mathrm{v}$.

Vedrørende personalet kan oplyses, at arkivar Viggo Petersen er blevet museumsinspektør i Alborg, og at $\mathrm{i}$ hans sted mag. art. Jørgen Witte er tiltrådt som arkivar. Personalet er udvidet med konservator S. Barner Olsson og arkivsekretærelev C. J. Lildholdt. Bibliotekar N. H. Kragh Nielsen, Rødding er deltidsbeskæf tiget ved ordning og registrering af landsarkivets efterhånden ret omfattende håndbibliotek.

P.K.I.

\section{Historiske Samlinger for Senderjylland}

Først lidt hen $\mathrm{i}$ det nye år kunne Historiske Samlinger flytte ind $\mathrm{i}$ de nyindrettede lokaler $\mathrm{i}$ den gamle landsarkivbygnings stueetage. Der er nu plads til udvidelse af samlingerne $i$ en lang årrakke fremover, og der er gode arbejdsbetingelser for personalet. Der er i beretningsåret $1 / 41973$ 31/3 1974 modtaget som gaver eller ved køb ialt 2972 fotografier og negativer, noget mindre end de foregående år, men til gengxld er der mange værdifulde afleveringer fra arvingerne efter kammerherreinde Ingeborg Refslund Thomsen og arkitekt Jep Fink. Lektor P. Beck, Abenrå, og lærer J. Holdt, Genner, har begge afleveret værdifulde billedsamlinger. Fotograferingen af gamle bygninger $i$ Tønder amt, der ledes af førstelærer $W$. 
Leick, er nu ved at være afsluttet, og der er nu skabt et værdifuldt billedmateriale til illustrering af, hvorledes de gamle vestslesvigske bondebygninger, der nu er ved at forsvinde, har set ud.

Båndsamlingen er blevet meget forøget ved den tidligere omtalte aflevering af afdøde lektor Karl Clausens mange bånd. Det bliver nu Historiske Samlingers opgave at pleje disse bånd, at fuldføre registreringen og sorge for, at de kan udnyttes videnskabeligt. Med de få midler, der er til rådighed, kan det nok knibe lige i øjeblikket.

$$
\text { P.K.I. }
$$

\section{Studieafdelingen ved Dansk Centralblbliotek for Sydslesvig}

Til tilsynsrådets beretnings- og budgetmøde den 5. juli 1973 forelå tilladelse til opslag af den ledige stilling som bibliotekslektor. Der var i Det sønderjyske Udvalg lagt vægt på, at stillingen ville kunne opslås og besættes $»$ med en mand, der ligesom Poul Kürstein vil kunne deltage $i$ det danske folkelige arbejde ved siden af den videnskabelige virksomhed ...* og at ... »den pågxldende er opmærksom på mulighederne for eventuelt at få samarbejde $i$ gang med det planlagte institut for grænseregionsforskning ved Folkehjem i Åbenrå «.

Efter opslag i august ansatte tilsynsrådet den 22. oktober 1973 lektor ved Islands universitet, dr. Johann Heinrich Jorgen Runge, f. 1926 i Flensborg. $\mathrm{Da}$ dr. Runge først kunne frigøres fra lektoratet ved universitetet $\mathrm{i}$ juni 1974, blev stillingen først tiltrådt fra 15. juni 1974.

Helmut Leckbands bog "Krigsfangelazarettet i Tamanskajagaden" udkom i september. Bogen fik en god modtagelse $i$ dagspressen, og det var nødvendigt at udsende 2. oplag i januar 1974.

Cand. phil. Carsten Mogensen blev 1.9.73 ansat som stipendiat med den opgave at studere vilkårene for det danske mindretal i Sydslesvig i perioden 1933-1945.

Cand. phil. Anders Ture Lindstrøm har fortsat sit arbejde med en bog om landet Slesvig-Holstens politiske historie efter 1945, og studieafdelingen håber, at arbejdet kan udgives $i$ løbet af $74 / 75$. Anders Ture Lindstrøms stipendiatansxttelse ophørte 31. 12. 1973.

På mødet 26. 1. vedtoges det at tilbyde Sydslesvigsk Forenings medlemmer i Slesvig Hermann Clausens: Der Aufbau der Demokratie in der Stadt Schleswig nach zwei Weltkriegen til en pris af $4 \mathrm{DM}$. Interessen for bogen har været stor. Foreningerne i Nordfrisland er tilbudt Nørre og Sønder Gøs herred til en pris af $8 \mathrm{DM}$. For samarbejdet med Historisk Samfund for Sønderjylland har vi sagt tak ved at overlade foreningen et antal eksemplarer af Vores egne vindver, udvalgte artikler fra Grenzfriedenshefte, redigeret af Poul Kürstein.

Tilsynsrådets sammensætning er uændret. 


\section{Haderslev museum}

Museets udgravningsvirksomhed er måske nok $i$ disse år præget af, at vi befinder os i mellemrummet mellem større, langsigtede opgaver. Som bekendt har vi lige afsluttet to store opgaver: Årupgård og Olmersdiget, og de nye større opgaver, som skal komme, er først under forberedelse på den måde, at prøveundersøgelser skal vise det berettigede $i$ eventuelt at sætte større kræfter ind. I en sådan periode bliver der muligheder for at få klaret mindre opgaver, som længe har trængt sig på, eller i hvert fald nogle af dem.

Et af disse "varige ønsker er at få noget mere at vide om stenalderbebyggelsen på østkysten. Denne bebyggelse svinder på en mærkelig måde hen $i$ lobet af bronzealderen, og der gives ingen gode forklaringer på, hvorfor det sker. Sådanne spørgsmål kan en enkelt udgravning ikke give svar på, men ved at øge vort materiale kan vi håbe på at komme svaret nærmere. I Hovst, Vilstrup sogn, blev en højt og frit beliggende langdysse undersøgt. Den havde indeholdt to gravkamre, hvortil svarede, at den var bygget af to gange. De vigtigste fund var et stort antal ravperler $i$ det ene kammer, og en af de sjældne kraveflasker $i$ det andet.

En af museets allervigtigste udgravninger var fundet af offerhøjen i Kastrup i 1937-38. Tæt ved siden af denne udgravning lå en lav, overpløjet gravhøj, og det ville vare af stor interesse at få at vide, om den havde noget med offerhøjen at gøre. Gravhøjen er nu undersøgt med det interessante resultat, at den er samtidig med offerhøjen - fra 100 årene efter Kristi fødsel, og at den indeholdt en stor stammekistegrav med et ret rigt udstyr: en fingerring af elektrum, bronzesager og lerkar. - Sent på sæsonen undersøgtes i Hejls en overpløjet gravhøj fra bronzealderen, der indeholdt to grave, den ene med en spiralarmring af bronze.

Der er $\mathrm{i}$ indeværende år foretaget to udgravninger, der måske kan udvikle sig til noget vigtigt. I Lønt er sidste års udgravning af en langdysse fortsat med en prøveundersøgelse af den tæet ved fjorden liggende og samtidige boplads. Hvad der foreløbig er set, ser meget lovende ud, og der er ingen tvivl om, at det er den til gravpladsen hørende boplads, der er tale om. Bopladsen er af ikke ringe udstrækning, og undersøgelsen vil blive fortsat $\mathrm{i}$ de kommende år.

Det samme kan siges om en anden provegravning, som med deltagelse af Nationalmuseets særlige sagkyndige med hensyn til voldsteder, inspektor Hans Stiesdahl, fandt sted i voldstedet Norrevold ved Arrild. Dette voldsted, der er et af de største i Nordslesvig, udmærker sig ved at være et af de få middelalderlige herresæder, som man har historiske efterretninger om. Fund og iagttagelser, man ved en undersøgelse kunne gøre ved dette voldsted, ville man her kunne bringe ind $\mathrm{i}$ en historisk sammenhæng. På tilskyndelse af sparekassedirektør H. P. Jensen, Agerskov, er det nu hensigten ved en serie undersøgelser $i$ de kommende år at skabe noget mere interesse om dette anlæg, og senere også bedre adgangsforhold til det. Dette sidste ønske stiller ejeren, gårdejer Bergholdt, sig meget velvillig overfor. 
Af de $\mathrm{i}$ årets løb afholdte udstillinger er der grund til at næune to. I december/januar afholdtes en udstilling om skomagervæsenet $i$ Haderslev $\mathrm{i}$ anledning af, at lauget kunne fejre 550 års jubilæum. Laugets to faner fra 1892 og 1924 blev i denne anledning deponeret på museet. - I sommeren 1974 vistes $\mathrm{i}$ anledning af den af verdensorganisationen arrangerede museumssommer en udstilling: på opdagelse $i$ oldtiden. Det var museets vigtigste udgravningsresultater fra de senere år, fund som normalt er pakket ned, som her blev illustreret med fotografier og tegninger.

Af de mange erhvervelser og modtagne gaver $i$ årets løb skal nxvnes nogle få. På en udstilling med Karen Yding købte museet et stykke billedbatik og på udstillingen med Nell Bernard en skulptur: Obelix.

En stor, jernbunden kiste med original bemaling og en skrivebordsstol stammende fra Hajstrup er af stiftamtmand J. Pinholt skænket museet. En meget smuk samling kniplinger og andet håndarbejde, som har tilhørt fhv. amtsforvalter v. Haffner er skænket museet, og fra afholdslogen "Pioneren « har museet modtaget faner, billeder og andre genstande.

Arkiv- og museumsforeningens foredrag var i efteråret 1973 viet vikingetidens byer og $\mathrm{i}$ foråret 1974 landkort og bybilleder fra Haderslev og Sønderjylland. Foreningens sommerudflugt gik i 1974 til de interessante udgravninger i Ribe.

I museets personale er der $\mathrm{i}$ årets løb sket den xndring, at museumspædagog Erik Jørgensen er fratrådt sin stilling, og mag. art. Stine Wiell er tiltrådt som museumspredagog ved museet.

Mere end nogen sinde har vi $\mathrm{i}$ dette år levet $\mathrm{i}$ forventningen om, at bygningen af det nye museum må blive en realitet.

H.N.

\section{Abenrå museum}

Til trods for, at restaureringen af billedsalen på Åbenrå museum har været skyld $i$, at udstillingsvirksomheden har måttet indskrænkes $i$ foråret 1974, har museet alligevel haft følgende udstillinger i regnskabsåret 1973-74:

5.5.-21.5.1973 malerier og tegninger af Christina Løwenthal. 26.5-10.6. 1973 malerier af Arne Sørensen og lærer Friis Christensen, Bevtoft. 30.6.22.7.1973 relieffer og skulpturer af Siegbert Amler og Uwe Lempelius, Flensborg. 28.7.-25.8.1973 Gerda Schmidt Panknin, russiske motiver. 10.8.-17.8.1973 demonstration af kartning og spinding af uld ved fru Asta Jepsen, Lille Strågård. 10.8.-1.10.1973 skibsmodeller bygget af kaptajn Closter, Stollig. 23.9.-7.10.1973 polske gobeliner og børnetegninger. 9.10.25.10.1973 tegninger, grafik og skulpturer af John Olsen. 26.10.-11.11.1973 salgsudstilling af U-landsgenstande for Terre des hommes. 27.10.-11.11. 1973 serigrafiske arbejder af Janek Sylla, Berlin. 15.11.-13.12.1973 grafik af Vibeke Mencke Nielsen. 17.12.1973-6.1.1974 illustrationer til børnebøger af Palle Bregnhøj. 9.12.-31.12.1973 oldemors juletræ. 


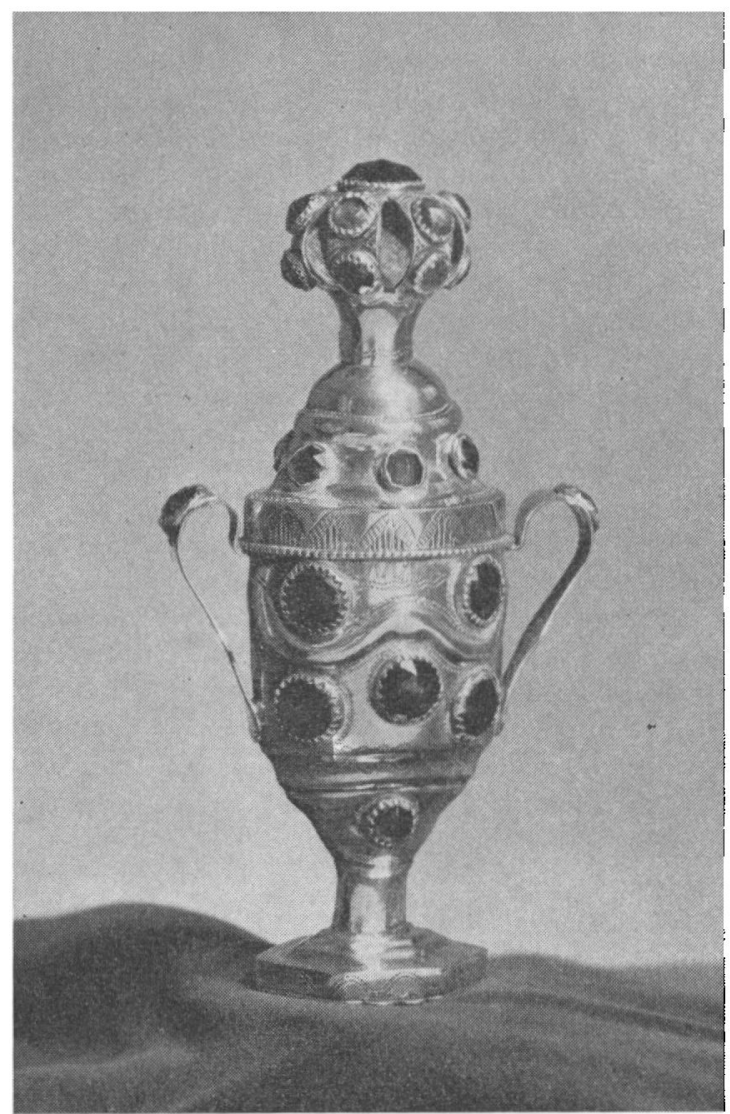

Hovedvandseg, udført af Abenrä-guldsmeden Andreas Heinrich Gottlieb Breundle (1811-1866).

Af bemærkelsesværdige nyerhvervelser har museet $i$ det forløbne år som gave fået tre pragtfulde miniaturebilleder af Abenrå-kaptajner. De to er tegnede af Paul Ipsen, København i 1789. Kunstneren var født på halligen Oland. Det tredie er malet af ukendt kunstner. Ligeledes har man som testamentarisk gave fàet et morsomt billede fra 1827 af selskabshuset „Frederikslyst «, der blev nedrevet i 1828 og genopført som rådhus i Ảbenrå. To dejlige blyantstegninger af xgteparret møller Fausbøl, Branderup mølle, tegnede af Ảbenrå-maleren Jes Jacobsen, der døde ganske ung i 1886, er også en gave, som museet er meget glad for. På Løjtland har museet købt et smukt Lorenz Nielsen-skab og til sølvsamlingen har man 
erhvervet flere hovedvandsxg og andre ting af Abenrå-guldsmede, dels som gaver og dels ved køb, således at man nu efterhånden har oparbejdet en både smuk og righoldig samling. Til kunstafdelingen har museet købt fire skulpturer, nemlig: Fåreklipperen af Nikolaus Wehding, Tjur af Gunnar Westmann, to drenge af Preben Køie-Nielsen og kampdværghøne af John Olsen. Wehdings arbejde er støbt $\mathrm{i}$ bly, de tre andre $\mathrm{i}$ bronce.

Det dårlige sommervejr har været gunstigt for besøgstallet.

H. J.

\section{Museet pà Sønderborg Slot}

Efter den endelige afslutning af den mangeårige restaurering af Sønderborg Slot, der markeredes ved en festlighed i riddersalen den 3. juli 1973, har museets arbejde været præget af forberedelser til samlingernes nyopstilling. Arkitekt for dette arbejde bliver professor, arkitekt m.a.a. Jørgen Bo. En del af forarbejderne er afsluttede; men endnu mangler meget, før de permanente basisudstillinger er fuldførte. I forste omgang arbejdes på den bygningshistoriske afdeling, der skal have nye plancher og nye montrer. Også arbejdet med nyopstilling af middelaldersamlingen er $\mathrm{i}$ fuld gang. Endvidere er der udført nye borde og stole til "slotskøkkenet «, hvor skoleelever kan spise medbragt mad. Også undervisningslokalerne er ved at få inventar - borde og stole i den store skolestue, reoler, borde og stole til grupperummet, skolekassen i den lille skolestue og kontormøbler til museumspxdagogens kontor.

Restaureringens afslutning har også åbnet muligheder for afholdelse af større særudstillinger. I forbindelse med de dansk-tyske dage $\mathrm{i}$ oktober 1973 arrangeredes en meget stor og smuk udstilling af moderne dansk møbelkunst og kunstindustri. Udstillingen, der arrangeredes af Foreningen Brugskunst og Industriel Design ved arkitekt Bernt, fyldte 1. sal i både sydfløj (møbler) og vestfløj (kunstindustri), og den må betragtes som måske den smukkeste udstilling, der nogensinde har været vist på slottet - især de store, enkle mobelrum var af højeste kvalitet. I tilknytning hertil vistes på 2. sal en udstilling om havearkitekt, professor C. Th. Sorensen, og i foredragssalen viste Sønderborg Fotoklub, i samarbejde med slesvig-holstenske kolleger, en udstilling af fotos, taget nord og syd for grænsen. Som et led $i$ de dansk-tyske dage var der endvidere udstillinger andre steder $i$ byen, først og fremmest på biblioteket, således at museet fungerede som et væsentligt led i et meget bredt udstillingssamarbejde over hele byen. Den officielle åbning fandt sted den 12. oktober i slottets riddersal.

Efter mobeludstillingen arrangerede museet en midlertidig opstilling, dels af nogle værksteder, først og fremmest snedker og skomager, dels af ældre redskaber, bl. a. fra hør- og uldtilberedning. Der blev også plads til en rakke netop rensede præstebilleder, der er deponerede fra St. Marie Kirke. Hele denne opstilling er dog kun midlertidig, men vil blive stående til den endelige opstilling af museets krigssamlinger. 
I løbet af vinteren og foråret etableredes derefter den største udstilling, museets eget personale nogensinde har bundet an med, "Nord og Syd i Skandinavien «. Den var muliggjort ved et anseligt tilskud fra Nordisk Kulturfond, og den kom til at fylde hele vestfløjens anden sal. Der er lånt genstande fra museer i Tromsø, Lulea, Stockholm, København og Esbjerg foruden fra adskillige private, og der er specielt til udstillingen udført et meget stort antal plancher, tegninger og fotostater. Både museets fastansatte og dets timelønnede personale - og ikke mindst dets militærnægtere var engagerede $\mathrm{i}$ dette arbejde $\mathrm{i}$ flere måneder. Udstillingen indledes med en oversigt over klima, jordbundsforhold og livsvilkår i Sønderjylland og ved Nordkalotten, og derefter følges $\mathrm{i}$ store træk udviklingen $\mathrm{i}$ de to områder gennem henholdsvis landbrugskultur og rensdyrnomadisme til moderne industrikultur $\mathrm{i}$ begge egne. Udstillingen har været en stor succes, og den forlængedes til den 31. oktober.

Sommeren 1974 var erklæret som dansk museumssommer, og i juni var Danmark desuden vært for den internationale museumskongres ICOM-74. Museet var herunder vært for en mindre arbejdsgruppe, der mødtes på Sandbjerg, og for hvem der arrangeredes en udflugt også til museerne i Tønder og Haderslev. Under kongressen åbnedes udstillingen $» N o r d$ og Syd i Skandinavien * ved en festlighed, hvor museets næstformand, revalideringschef Sv. A. Hellesen, holdt åbningstalen, og forud herfor havde Sønderborg kommune været vært for de udenlandske gæster ved en reception med pølsebord i slotskøkkenet. Museet deltog iøvrigt i museumssommeren med en række genstande til en fællesudstilling i Handelsbanken i Østergade i Kobenhavn.

Museet har endvidere vist et par mindre særudstillinger. Den ene var en polsk plakatudstilling, der var et led $i$ et polsk kulturarrangement med udstillinger også i Tonder og Ảbenrå, det andet var en gronlandsk fotoudstilling. Den sidste var suppleret med en fornem Gronlands-samling, lånt hos læege S. Andersen, Gråsten og med Grønlands-bøger fra biblioteket.

Disse arrangementer har foruden den afsluttede restaurering væsentligt bidraget til det gode besøgstal på over 60.000 . Undervisningsafdelingens arbejde er fortsat udbygget, dels med indretning af fire emnekasser, der $\mathrm{i}$ nært samarbejde med skolecentralen udlånes til lokale skoler, dels med udgivelse af duplikerede hefter. Foruden det stadig godt solgte »Sønderjyske Madopskrifter * foreligger nu "Sønderjysk historisk $A B C$, særlig beregnet på lejrskoler, samt en lille vejledning om Dorotheas kapel og en vejviser til museet. De to sidstnævnte foreligger, ligesom kataloget til den skandinaviske udstilling, også på tysk. Samarbejdet med skolecentralen er udvidet, bl. a. er et lille hefte om museets tilbud til skolerne ad denne vej fordelt til samtlige skoler $i$ amtet.

Museet har fortsat modtaget adskillige gaver og gjort en del indkøb. Møntsamlingen er øget med adskillige gode køb, både af mønter og medailler. Til tekstilsamlingen er indkøbt et stort beiderwand-tæeppe og nogle længder olmerdug, foruden flere dragtdele og broderier. Også til denne 
afdeling er der som $\mathrm{i}$ det hele taget til den kulturhistoriske afdeling modtaget mange gaver. Til den historiske afdeling er modtaget nogle våben, bl. a. hovedet til en morgenstjerne «, muligvis fra 1600-tallet og et par uniformsdele samt indkøbt enkelte våben og en "krudtprøvepistol " fra ca. 1750, formentlig af dansk fabrikat. Billedsamlingen er vokset ved adskillige gaver. Endelig er til kunstsamlingen indkøbt eller skænket malerier af W. Birchner, Johanne From Clausen og A. E. Kieldrup.

Museets etnologiske undersogelser er fortsat med arkivarbejde vedr. Havbogade og med publicering af stoffet vedr. russiske krigsfanger. To nye spørgelister (om legetøj og om juleskikke) er udarbejdede og til sidstnævnte er modtaget 100 breve fra Jydske Tidende, indkommet $i$ december 1973. Fru Adriansen har publiceret materiale i Sønderjysk Månedsskrift, og J. Slettebo har leveret en artikel til museumsrådets nye årbog "Nordslesvigske Museer " samt anmeldelser i "Fortid og Nutidk.

$\mathrm{I}$ årets løb har J. Slettebo deltaget $\mathrm{i}$ museumsforeningens og Dansk historisk Fallesforenings årsmøde i Maribo, i museumsforeningens drøftelser $p^{2}$ Hindsgavl og dens kursus $i$ Lakolk, $i$ den internationale museumskongres ICOM-74 (Sønderborg-København) og i bestyrelsesmøder i ICOM's danske nationalkomité og i DHF samt i redaktionsmøder $\mathrm{i} \gg$ Fortid og Nutid«. Fru I. Adriansen har været på studierejse til Sverige, hvor hun, fordelt over 2 omgange, har studeret undervisningsforhold på 16 svenske museer.

J.S.

\section{Tonder museum}

Siden sidste beretning i Sønderjyske Årbøger er endelig gennemført en gennem den sidste menneskealder påtænkt rundgang $\mathrm{i}$ museets 1 . etage. Det er sket $\mathrm{i}$ forbindelse med nedlrggelsen af kustodeboligen, der var indrettet $i$ en 1836 over den oprindelig tofløjede kasematbygning påklistret tagetage. De gamle mure har kunnet restitueres og det smukke - stadig skjulte gårdanlæg fores tilbage til den form, det havde ved porthusets ombygning i 1741. Takket vare gammelt billedmateriale og udførlige arkivalier (fin assistance fra landsarkivet) har det været muligt at genopdage en nydelig bygning, der - når pengene engang bevilges eller skaffes - vil komme frem ved blot at fjerne det hæslige tag. Der er tale om Tonder bys næstældste bygning (ca. 1530).

Rundgangen fører fra et nyrestaureret rum over drabantsalen ned gennem forbindelsesfløjen til den såkaldte skovrøyske celle, hint rum, hvor Skovrøy for 80 àr siden sad "for en ordens skyld «, og dermed ledes publikum ned gennem de gemytlige byfængsler fra 1811 med de mange morsomme væginskriptioner.

Yderligere er et af magasinrummene $i$ den nye museumsbygning indrettet til udstillingsrum for museets nyrestaurerede samling af ovne og ovnplader. Tillige fungerer den som skolestue og mødelokale. Det er hensigten at inddrage yderligere to af kxldermagasinerne til udstillinger, idet 
en speciel afdeling for marsken er påtænkt. Tilslutning til byens fjernvarmeanlæg gav mulighed for udvidelse af museets værkstedsareal.

Museets 50-års jubilæum fejredes i februar 1974 med udgivelsen af en fornem publikation, hvortil konsul George Jorck og hustru Emma Jorcks fond ydede tilskud. I juni forelå et specialkatalog over museets flisesamling og i september en ny 4-års beretning (1970-74).

Der har været afholdt to særudstillinger, en om gammelt dansk apotekerinventar $i$ anledning af Tonder Apoteks 350 års jubilxum og en om belysning gennem tiderne.

Af skolepædagogisk arbejde kan fremhæves udarbejdelsen af en $\gg$ oldtidskasse* med våbentyper fra zldre stenalder til bronzealder, samt en skolematerialemappe med opgaveforslag og vejledning til emnerne: Stilarter, folkekunst og hollandske fliser. Larer Per Loldrup har her udført et forbilledligt arbejde.

Hvad nyerhvervelser angår, skal her fremhæves et karakteristisk Tønderstandur af F. C. Matthiesen, 1760, med gedigent 8-døgns værk, samt en unik (og komplet) samling af dragtstik fra Westphalens Monumenta inedita 1739, i alt 56 dragtbilleder. Sølvsamlingen er bl. a. forøget med en sukkerspand med blåt glas af Peter Petersen, Tonder, fajancesamlingen med to urtepotter og en barselspand fra Kellinghusen.

Nok så vigtigt er det, at der er foretaget betydningsfulde restaureringer af museets møbler, også fra magasinerne. Den gamle plan om på slotsbanken at få markeret grundridset af det 0.1750 nedbrudte slot kan snart føres ud $i$ livet, efter at man i december 1973 fik fjernet resterne af den store gasbeholder fra 1946, der var anbragt i slotsgårdens midte.

Besøgstallet var kalenderåret 1973: 30.869. De ni måneder af 1974 godt 24.000 .

S. Sch.

\section{Sønderjyllands kunstmuseum}

Aktiviteten på landsdelens kunstmuseum har 1973/74 været overvældende. Mindre ved kunstindkøb end $\mathrm{i}$ kraft af udstillinger:

1) Polsk grafik. Sept. 1973.

2) Lars Bo. Grafik. Sept./okt. 1973.

3) Visuelt 73. Norske malerier og skulpturer. Okt./nov. 1973.

4) Aksel Jensen. Tegninger. Nov. 1973.

5) Dan Sterup Hansen. Grafik. Dec. 1973.

6) Børnetegninger i anl. af julen. Dec./jan. 1973.

7) Tage Stentoft. Grafik. Jan. 1974.

8) Hollandske serigrafier. Jan. 1974.

9) Konkretister. Maleri, serigrafi, skulptur mm. Jan./febr. 1974.

10) Preben Reinicke. Malerier. Febr. 1974.

11) Peter Nicolaisen. Malerier. Febr./marts 1974.

12) Seppo Mattinen. Tegninger. Febr./marts 1974. 
13) Palle Nielsen og hans elever. Grafik. Marts 1974.

14) Konfrontationer. Fotos. Marts/april 1974.

15) Helle Vibeke Erichsen. Grafik. Marts/april 1974.

16) Katolske tryk. Kobberstik. April 1974.

17) Herman Stilling. Maleri, grafik mm. Apr./maj 1974.

18) Palle Bregnhøj. Tegninger. Apr./maj 1974.

19) Hollandske papirklip. Maj/juni 1974.

20) Edvard Munch. Grafik. Juni/juli 1974.

21) Gunnar Bay Nielsen. Malerier. Juni/juli 1974.

22) Sven Enselmann. Grafik. Juli 1974.

23) Walther Kunau. Grafik. Aug./sept. 1974.

24) A. Paul Weber. Grafik. Juli/aug. 1974.

25) Ole Finn Andersen. Tusch. Aug. 1974.

26) Svensk nutidskunst. Aug./sept. 1974.

27) K. Bjørn Knudsen. Malerier. Sept. 1974.

28) E. Bjørn Knudsen. Stoftryk. Sept. 1974.

29) Reidar Auli. Malerier. Sept./okt. 1974.

Museet har herudover arrangeret mindre udstillinger på Åbenrå landsbibliotek, Rødding højskole, Nybøl plejehjem, Gråsten folkeskole, Digeskolen i Højer, Bregnebjergskolen i Vojens, skolen i Broager, mm.

Af årets kunstindkøb skal nævnes skulpturer af Sv. Wiig Hansen, Erik Heide og Nina Sundbye, malerier af Fr. Rohde, Mogens Lehmann, Steffen Jørgensen, Carl-Henning Petersen, Olaf Rude, Ole Schwalbe, grafiske arbejder af Else Fischer-Hansen, Karl Aage Riget, Richard Mortensen, Ejler Bille, Thomas Arnel mm.

Administrativt er med nedsættelsen af et indkøbs- og udstillingsudvalg på 5 medlemmer og ansættelsen af maleren Erik Lagoni Jakobsen som konsulent styringen af landsdelsmuseet centraliseret, omend ikke forenklet. Med denne form skulle ensidighed kunne undgås.

I forbindelse med udstillingerne er fremstillet en række kataloger og plakater, og et programhæf te for udstillingerne $i$ vinterhalvåret er udsendt (og kan rekvireres). Der har været arrangeret et enkelt kunstforedrag (museumsdirektør Peter Anker, Bergen), som også holdtes på højskolen i Løgumkloster, ligesom museet har været ramme omkring en række musikalske foranstaltninger og filmfremvisninger.

S. Sch.

\section{Kunstmuseet Holmen, Løgumkloster}

Udover den sædvanlige årlige nyophængning af Olivia Holm-Møllers arbejder har museet $\mathrm{i}$ år haft gxstekunstnere, idet malersammenslutningen »Violet sol « beslaglagde hovedparten af lokalerne til en udstilling $i$ tiden 6.-21. april.

"Violet sol «s medlemmer er: Egon Bjerg Nielsen, Peter Dohm, Bjarne 
Esbensen, Finn Hjortskov, Gunnar Møller, Ole Prip Hansen og Niels Reumert, der hver havde sendt 6-7 arbejder. Det er unge kunstnere hver med sit »ansigt «, men som dog delvis har præget hinanden gennem tidligere udstillingsfallesskab.

For at tilhængere af Olivia Holm-Møller ikke skulle komme helt forgæves $i$ denne periode, var der samlet prover af hendes kunst $i$ et enkelt rum.

Endnu en gæstekunstner har glædet museets besøgende. I sidste halvdel af september har der i samarbejde med Sønderjyllands kunstmuseum i Tonder været vist arbejder af den norske maler Reidar Auli.

En længe planlagt udstilling af Olivia Holm-Møllers hovedværk: "Slægten " fandt sted i oktober. Det var dog kun de 7 af de 9 billeder, der hører til serien, der var udstillet. Dette arrangement har kunnet gennemføres ved stor velvilje fra Askov Højskole, der ejer de 6 af billederne - de hænger normalt $\mathrm{i}$ højskolens festsal. Tidligere forstander Knud Hansen, Askov, har fortolket billederne, og denne fortolkning har de besøgende kunnet høre gennem museets højtalere og derved fået yderligere udbytte af de enkelte motiver.

E. K.

\section{"Samlingen af arbejdsredskaber og bondemobler « pả Jacob Mlchelsens gárd I Kolstrup.}

Torsdag d. 11. oktober 1973 holdres årsmødet $\mathrm{i}$ den selvejende institution. Formanden apoteker Niels $C$. Michelsen aflagde beretning, hvor han omtalte udstillingen kaldet Rughøsten og bondebrødet «, som åbnede Mikkelsdag d. 29. sept. 1973, og som blev stående til langt hen mod slutningen af året, da flere foreninger havde bedt om at måtte komme og se udstillingen.

Selvom specialmuseet takket være museumsmedhjælper Tage Ravn allerede nu opbevarer beskrivelsen af mange redskaber og deres arbejdsmetoder i registreringsarkivet, ligger der fortsat et stort arbejde forude, forend hele museets samling er registreret. I årets løb har museet modtaget gaver fra Fru Didde Beyer, fru Anna Ølgaard, frk. Marie Jacobsen, frk. Gunder Nissen, fru Hede Hansen, frk. Sofie Schrøder, hr. Max Friedrichsen, hr. Hans Knudsen og hr. Thorvald Jessen.

Støttekredsen havde bidraget med 56 indbetalinger.

Til styrelsen nyvalgtes lærerinde fru Ellen Christensen og lægesekretær fru Kirsten Petersen.

A. H.M.

\section{Prisopgaven}

Den af Historisk Samfund for Sønderjylland udsatte prisopgave om et emne med tilknytning til Gråsten har kun fundet én besvarelse. Under 
mærket K. V. er indleveret en afhandling med titlen $»$ Gråsten Slot og de forskellige ejere indtil $1845 \%$. Afhandlingen omfatter 34 sider i A4 format. Den er uden videnskabeligt apparat.

Ved nærmere eftersyn ses, at den i vid udstrækning, men uden kildehenvisning følger A. D. Jørgensens artikel i Sønderjyske Arbøger 1889 om "Gråstens ældste Historie«. Selv $\mathrm{i}$ den sproglige formulering holder forfatteren sig ofte nøje til artiklen, således at sproget visse steder kun er ændret en smule $\mathrm{i}$ forhold til A. D. Jørgensens ordvalg. Eksempler herpå findes bl. a. s. 4 , s. 5 og s. 6 .

I skildringen af storkansleren Frederik Ahlefeldt og hans efterkommere er der fra den almindelige historiske litteratur inddraget yderligere materiale, dog kun i ringe grad til belysning af forholdene på og ved Gråsten slot, men mere til belysning af de pågxldendes deltagelse $\mathrm{i}$ tidens politiske og militære aktioner.

Afhandlingen imødekommer ikke de elementære fordringer, der må stilles til besvarelsen af en prisopgave, og de i Historisk Samfund for Sønderjyllands opslag stillede krav om videnskabelig dokumentation og et omfang på mindst $150 \mathrm{~A} 4$ sider er ikke blevet opfyldt.

Det af Historisk Samfund for Sønderjylland nedsatte bedømmelsesudvalg er nået til det resultat, at afhandlingen ikke kan belønnes med nogen pris.

Troels Fink. H. V. Gregersen. Olaf Olsen.

\section{Amtskredsenes arbejde}

\section{Haderslev amtskreds}

Den 15. maj holdt Haderslev amtskreds generalforsamling og møde i Gram. Der begyndtes med en udflugt til teglværksgraven under ledelse af lektor W. Buch, Haderslev, der fortalte om stedets geologiske historie og forklarede om de mange forsteninger, som findes her. Generalforsamlingen holdtes i Den gamle Kro. Helge Jacobsen, Haderslev, genvalgtes og i stedet for fru Anne Marie Skau, Nygaard, der blev mindet, valgtes Søren Rasmussen, Hygum. Efter kaffen fortsattes mødet, hvor Musse Skærlund berettede om Grams museumsplaner, idet Gram Museumsforening overtager en fløj af Gram slot til brug for et kommende egnsmuseum. Der blev også fortalt om den dramatiske bjergning af den allerede berømte hvalfisk Moby Dick «. Der var 32 deltagere.

Sammen med Haderslev museumsforening holdtes den 15. juni en udflugt til udgravningerne af vikingetidens Ribe. Arkæologistuderende $O$. Schørring talte om fundene og den interessante udvikling i det første Ribe. Egentlige huse og gader var endnu ikke fundet, men de store 2-3 m tykke affaldslag gjorde indtryk. Udsigterne til at høre nyt fra det gamle Ribe i de kommende år bedømtes som lyse, trods huse og gader, der jo sætter 
snævre grænser for, hvor der kan graves. Der var ca. 100 deltagere.

Egnsvandringen den 25. august gik til området nord for Kongeån. Ved Skodborghus fortalte undertegnede om slottet og egnens skxbne. Mindestenen på voldstedet fortæller, at her stod i 600 år det kongelige slot Skodborghus. Der fortsattes til Sønderskov herregård. Her talte Valdemar Andersen om Thomas Juels gamle gård. Slottet, der er $\mathrm{i}$ forfald, talte ved sin stolte rejsning og solide håndværk stærkt til tilskuerne om fortiden. Valdemar Andersen nævnte de trodsige bønder, der ikke var så underkuede endda. Det sidste sted på turen var Foldingbro, hvor der blev drukket kaffe. Valdemar Andersen fortalte om stedet, broerne og tolden ved det gamle græenseoverfartssted. Den rolige og gode fremstilling bidrog væxsentlig til eftermiddagens indhold. Der var ca. 60 deltagere.

K. H.

\section{Ábenrá amtskreds}

Søndag den 19. august 1973 holdtes $\mathrm{i}$ forbindelse med Folkeligt Samfund den traditionelle udflugt, der denne gang gik til Tønder museum. Det var meningen, at man ville have besegt Trøjborg; men da klokkespillet i Løgumkloster blev indviet samme dag, xndrede man planerne og tog efter at have drukket kaffe på Højkro i Sdr. Sejerslev ad mange smukke sideveje til Løgumkloster, hvor Sønderjyllands Symfoniorkester gav en koncert i forbindelse med klokkespillet, der blev betjent af den hollandske professor Leen Hart. Efter den interessante oplevelse kørte man over Vongshøj med den storslåede udsigt til Bedsted, hvor man dvalede ved mindesmærket for J. Th. Lundby. Her holdt lektor Peter Beck, Ảbenrå, foredrag om kunstneren. Den 12. marts 1974 var der i Varnæs skole et arrangement med foredrag af Urban Schrøder om spedalskhed i Varnæs sogn og af Ib Andersen om degn Gammelgård, Varnxs. Skolens gymnastiksal var fyldt, og aftenen sluttede med, at amtsformanden propaganderede for Historisk Samfund. Der var fremlagt tryksager $\mathrm{m}$. $\mathrm{m}$.

Den 21. marts 1974 havde amtskredsen arrangeret et møde i Felsted skole, hvor førstelærer Jensen, tidl. Skovbøl, holdt foredrag om Justitsråd Koch contra Christian den VI, blade af sognets skolehistorie. Også der var fuldt hus, og der blev også der gjort et fremstød for Historisk Samfund.

Ved generalforsamlingen den 6. maj 1974, der denne gang atter holdtes på Folkehjem som for restaureringen, talte lærer Ib Andersen, Varnæs, om degn Gammelgård, Varnæs. Alle valg var genvalg.

Søndag, den 25. august arrangerede amtskredsen $\mathrm{i}$ forbindelse med Folkeligt Samfund den planlagte udflugt til Ullerup og omegn, inspireret af lektor Peter Becks bog: »Dansk dreng i Sundeved « og derfor også ledet af Peter Beck. Der var som ventet stor tilslutning. De to busser samt en mængde privatbiler standsede først ved Ullerup præstegård, hvor man beså den dejlige park, hvorefter man tog til Ullerup kirke. Her indledede lektor Beck, efter at organisten havde præluderet meget smukt, med at læse $\mathrm{Da}$ - 
vids 103 salme, den samme som Willy Brandt laste ved sit besøg i Israel. De op imod hundrede deltagere sang så en af Grundtvigs salmer, digtet over samme emne, og derefter fortalte pastor Seedorff-Rasmussen om både præstegården og kirken. Fra kirken gik man over i Ullerup kro, hvor lektor Beck veloplagt og levende fortalte træk af sognets historie og forklarede, hvad man nu ville få at se på resten af vejen. Ved Sandbjerg fortalte Beck om Karen Blixens relation til Sandbjerg, og ved Sottrupskov fik man, foruden at man nød den smukke udsigt, lidt at vide om preussernes overgang til Als. Til slut kørte man videre forbi Nydam mose, Nørremølle og hjem. De store forventninger til denne udflugt blev til fulde indfriet.

H. J.

\section{Senderborg amtskreds}

Der holdtes møde d. 9. november 1973 med 20 deltagere på Sønderborg bibliotek. Dr. theol. G. Weitling fortalte om forhistorien og bevæggrundene for udstedelsen af nødpengesedler i tiden 1914-1923. Forstelærer Karl Lund sørgede for en fyldig udstilling af og viste $i$ lysbilleder $*$ Nødpengesedlerne i Nordslesvig under og efter 1. verdenskrig med særlig henblik på sedler udstedt i Sønderborg amtsrådskreds.*

Den 14. marts var der møde på Danebod højskole med ca. 100 deltagere. Forstander Gunner Rasmussen skildrede oprettelsen af højskolen og dens historie, og gårdejer Chr. Speggers, Miang, fortalte om dagligt liv på en alsisk bondegård omkring 1914.

Der var oplæsning ved gårdejer Peter Clausen, Kettingskov, og musikalsk underholdning ved fru Marie Simonsen.

Sommerudflugten gik til Ảbenrå med generalforsamling i „Folkehjem«s billedsal i Abenrå. Lektor Hans Gunner Bojsen, Sønderborg, nyvalgtes til bestyrelsen. Efter kaffedrikning fortalte museumsinspektør Holger Jacobsen livligt og inciterende om *Folkehjem « og byggeriet samt gav en forhåndsorientering om byens museum. De ca. 50 deltagere så sig herefter om i det nye Folkehjem, hvorefter man aflagde et besøg på museet under Holger Jacobsens ledelse.

O. $B$.

\section{Tonder amtskreds}

Den 7. marts 1974 fortalte pastor J. Algreen-Petersen i Bredebro om digterinden Anna, datter af pastor Lautrup i Brede, samt lidt om kniplingshandler Jens Wulff, Brede. Der var 30 deltagere i mødet. Den 4. april holdtes årsmøde og generalforsamling på "Tonderhus« med ca. 90 deltagere. Her fortalte fhv. viceskoleinspektør Werner Christiansen, Tønder, om gamle Tønder-virksomheder, deres indehavere samt om deres betydning for byen og videre ud $i$ landet. 
Skoleinspektør S. N. Christensen, Ravsted, viste lysbilleder fra sidste års egnsvandring på hallig Hooge.

Den 22. juni startede dette års egnsvandring i Treja danske skole, hvor skoleleder $\mathrm{H}$. Henken orienterede. Turen gik videre langs Trenen, hvor pastor Karstoft, Tarp, var leder. Der sluttedes i Oversø kirke. Turen var en stor oplevelse for de 20 deltagere.

Sammen med styrelserne for de lokale historiske foreninger $\mathrm{i}$ kredsen holdtes der den 13. marts i Løgumkloster møde angående aktivitet for at øge interessen for det historiske arbejde. Drøftelsen blev videreført på et møde den 9. september.

Fhv. lærer W. Leick, Tønder, er nu næsten færdig med fotograferingen af gamle huse og gårde i Tønderkredsen.

$$
\text { S. N. }
$$

\section{Sydslesvigs amtskreds}

Efterårsmødet blev afholdt torsdag den 29. november 1973 i Slesvig. Generalkonsul Troels Fink talte om det spæendende emne "De gottorpske fyrster $\%$. Den talrige forsamling lyttede med stor interesse. Det var et foredrag, som længe vil blive husket.

Torsdag den 28. marts 1974 holdt vi generalforsamling på Centralbiblioteket i Flensborg. Professor Troels Fink var mødeleder. Ars- og kasseberetningerne blev godkendt. Pastor Paul Tappe blev genvalgt. Styrelsens forslag med hensyn til foranstaltninger i resten af året 1974 blev godkendt. Efter kaffebordet talte museumsdirektor, dr. phil. Sigurd Schoubye om »Folkekunst i Sonderjylland .

Aftenvandringen 1974 gennemførtes torsdag den 20. juni. Den havde Holmen i Slesvig som mål og var velbesegt. Man startede med et besøg i det gamle Sct. Johanniskloster, hvor klosterprovst dr. Henning von Rumohr fortalte om husets historie og viste rundt. Formanden kunne i sin velkomsttale byde gester fra hele Sydslesvig og fra Danmark velkommen.

Gxsterne blev derefter vist rundt $\mathrm{i}$ huset og så bl. a. på refektoriet, der tjener som mødesal, og på kapitelsalen, der rummer et lille bibliotek samt klostrets arkiv.

På Historisk Samfunds vegne overrakte Lars Schubert efter endt rundgang som tak en boggave til dr. Henning von Rumohr.

I tilslutning til besøget på Johannisklostret foretog deltagerne en vandring over Holmen, Slesvig bys ældgamle fiskerkvarter. Her fortalte overlærer Ernst Vollertsen, der selv stammer fra en Holm-familie og er opvokset her, interessante ting om denne smukke lille bydel og dens særpræe.

Holmen har stadig den for en typiske bebyggelse med gavlhuse, selv om Holmen forlængst er ophørt med at være en ø. Vollertsen kunne fortxlle om selve fiskeriets teknik, dets retslige traditioner og vanskeligheder i fiskernes tilværelse, især deres hårde arbejde under isfiskeriet om vinteren.

Samtidig fik aftenvandringens deltagere en udforlig redegørelse om Holmens begravelsesgilde, der netop $\mathrm{i}$ denne weekend holdt sin årsfest 
med de mange smukke, gamle - for fremmede undertiden uforståelige ritualer. Når gilde- og laugsvæsenet i Slesvig har et særdeles fast ståsted, har ikke mindst den lille befolkningsgruppe på Holmen en væsentlig andel heri.

For alle aftenvandringens deltagere var turen gennem Sct. Johannisklostret og over Holmen en stor oplevelse. Stedets særpræg og rigdom på historie var for mange sikkert en overraskelse.

I år var det Sydslesvigs amtskreds tur til at gennemføre Historisk Søndag. Den blev holdt søndag den 4, august i det gamle Sydtønder amt med følgende mødesteder:

Ladelund - her besøgtes kirken og KZ-gravene under ledelse af skolelederJørgen Petersen.

Læk - syd for kroen Carlsborg tog overlærer Johann Mikkelsen imod gxsterne og fortalte om den vestlige Oksevej.

Enge - i kirken fortalte pastor Paul Tappe.

Bredsted - i det frisiske Institut redegjorde cand. mag. V. Tams Jørgensen og Dr. Holander for det frisiske arbejde.

Risum/Lindholm - her fik vi lejlighed til både at besøge skolen og den nyindrettede bornehave.

Dedsbøl/Nibøl - på museet tog sekretær Alfred Boysen imod.

Trods et øsende regnvejr havde vi godt besøg. Der regnes med, at der i alt har varet 200 mennesker undervejs. I Ladelund kirke var der 150 besøgende, ved Oksevejen 50, i Enge kirke 150, på det frisiske Institut 80, i Risum/Lindholm 50, og i museet i Dedsbøl 60 deltagere.

Søndag den 1. september 1974 var vi på sommerudflugt til Büdelsdorf ved Rendsborg, hvor vi besøgte Carlshüttes museum i Hollerstrasse. Museumsleder, fhv. driftsleder Jürgen Möller, fortalte om sit virke i Carlshütte, hvor han begyndte som lærling og arbejdede sig op til driftsleder. Med dette som grundlag, var hans redegørelse om grundlæggelsen af Ahlmannværket ved Marcus Hartwig Holler i 1827 en oplevelse at følge. Med kong Frederik VI's tilladelse blev fabrikken startet, og statholder Carl af Hessen lagde navn til foretagendet.

Sommerudflugten blev en familietur, hvor ungdom og børn var med. På Amtmandsgården $\mathrm{i}$ Torstrasse fortalte sekretær Hxbel om det danske arbejde $\mathrm{i}$ Rendsborg by. Efter kaffebordet gik man en tur igennem huset. I Fritidshjemmet fortalte lederen Vilh. Dierking om ungdomsarbejdet i Rendsborg. Det var i alle måder en vellykket tur.

L. H. S. 


\title{
Årsberetning og regnskab $1973-74$
}

\author{
Ved Peter Kr. Iversen og H. Lildholdt
}

Historisk Samfund for Sønderjylland holdt årsmøde søndag den 12. maj 1974 på Folkehjem i Abenrå. Mødet begyndte kl. 14, og der var mødt ca. 135 medlemmer.

Formanden, landsarkivar Peter Kr. Iversen bød velkommen, særligt til vore æresmedlemmer, Troels Fink, H. Neumann og M. Kamphövener og foreslog som dirigent formanden for Ảbenrå amtskreds, museumsleder Holger Jacobsen, hvis valg bifaldtes af forsamlingen. Dirigenten konstaterede, at årsmedet var lovligt indvarslet, og gav ordet til formanden, som aflagde følgende beretning:

Helt naturligt har året 1973-74 for os $\mathrm{i}$ den snævre ledelse og $\mathrm{i}$ den daglige administration først og fremmest været præget af landsarkivets ferdiggørelse og af det ekstraordinære arbejde, der fulgte med. Først måtte den gamle bygning, hvor Historisk Samfunds kontor og betydelige dele af boglageret var placeret, rømmes, og kontor og boglager flyttes midlertidigt til den nye bygning. Hovedparten af bestanden af bøger og tidsskrifter blev stående $\mathrm{i}$ flyttekasser, og ekspeditionen har derfor $\mathrm{i}$ en periode kun været mulig $\mathrm{i}$ begræenset omfang. $\mathrm{Da}$ ombygningen af den gamle arkivbygning var færdig ved nytårstid, skulle der flyttes tilbage igen, og bøger og sager måtte pakkes ud og placeres på blivende sted. Historisk Samfund og Historiske Samlinger har nu fået gode lokaler og arbejdsrum i stueetagen, og i tagetagen er det ganske betydelige boglager anbragt. Vel for første gang har foreningens bøger og tidsskrifter kunnet samles på et sted, og det vil nu helt anderledes end forhen være muligt at holde tal på beholdningerne. Der skal også ved denne lejlighed lyde en hjertelig tak til de bevilgende myndigheder og ministeriet for kulturelle anliggender for de gode arbejdsbetingelser, der er givet Historisk Samfund $\mathrm{i}$ de nyindrettede lokaler, og jeg kan i denne forbindelse tilføje, at også andre historiske organisationer er velkomne til at benytte lokaler og faciliteter på landsarkivet. Det er simpelthen derfor, at der bl. a. er bygget en kombineret møde- og udstillingssal. Vi håber, at den vil finde rige anvendelsesmuligheder ved foredrag, udstillinger, kurser o. a. 
Flytningen og ibrugtagningen af de nye lokaler er nok en af grundene til, at foreningens mere udadvendte arbejde ikke har kunnet understottes så meget, som vi gerne ville her fra sekretariatet. Vi har fra ledelsens side måttet være tilbageholdende med at animere til nye aktiviteter, men til trods herfor har medlemstallet holdt sig, således at vi den 1. april har 2822 medlemmer mod 2819 i fjor. Men det er ikke helt den samme medlemskreds. Vi har fornøjelsen at kunne byde 144 nye medlemmer velkommen $i$ vor kreds. Ved dødsfald, fraflytning og af andre grunde er der som sæedvanligt sket et betydeligt frafald af medlemmer, og uden tilgang af nye ville foreningen snart skrumpe ind. Helt oplagt er det, at vi mister medlemmer, fordi der ved flytning ikke opgives ny adresse. Måske burde vi of re noget mere tid på at efterspore disse medlemmers nye bopxl. Vi kan imidlertid kun udtrykke tilfredshed over et stabilt medlemstal, og det er vort håb, at medlemmerne trods den uomgrengeligt nødvendige forbøjelse af kontingentet fra 20 til $30 \mathrm{kr}$., som styrelsen har vedtaget, fortsat vil slutte op om foreningen. Forhøjelsen af kontingentet er udelukkende betinget af stigende trykkeomkostninger, hvorimod vi endnu ikke har kunnet forhøje honoraret for bidrag til årbøgerne. Gennem en lang årrxkke har det været reglen, at medlemskontingentet har skullet dxkke samtlige omkostninger ved udgivelsen af Sonderjyske Årbøger, men dette har ikke været tilfældet i det sidste par år. Vi har måttet tære på ressourcer, der var bestemt til andre formål, $i$ det sidste regnskabsår ca. $10.000 \mathrm{kr}$., og derfor har vi nu måttet gribe til denne ikke uvæsentlige forhøjelse af kontingentet. I sammenligning med prisen på andre bøger må et bind Sønderjyske Årbøger på op imod 300 sider dog siges at være rimelig.

Vi udsendte årbogen $1973 \mathrm{i}$ et omfang på 272 sider og med et indhold, der i tid strakte sig fra middelalder til nutid. H. V. Gregersen skrev om studedrift og told langs hrervejen og Valdemar Andersen om Christian IV's bryllup på Hansborg. Dorrit Andersen udgav redaktør Nis Petersens erindringer fra Flensborg Avis i 1890'erne, Gottlieb Japsen fremsatte nogle betragtninger over den danske bevægelse i Nordslesvig, og Frants Thygesen kommenterede Bjarne W. Frederiksens bog om Danmarks sydslesvigpolitik efter 1945; men det fyldigste og vigtigste bidrag var dog den unge historiker Inger Svanes afhandling om Vxlgerforeningen og de dansksindede nordslesvigeres politik 1906-10. Et stort, nyt materiale fra privatarkiver er her fremlagt. Desuden indeholdt årbøgerne som sædvanligt anmeldelser og meddelelser fra landsdelens historiske institutioner. For første gang var årbogen efter Hejmdals Bogtrykkeris nedlæggelse trykt i P. J. Schmidts bogtrykkeri i Vojens, og vi kan være godt tilfreds med den tekniske udførelse.

Vort andet tidsskrift, Sønderjysk Manedsskrift, har haft en fortsat glædelig udvikling. Medens holdertallet sidste år kunne opgøres til 1478, er det nu 1517, altså en fremgang på 39. Heri er indbefattet de 100 sydslesvigske holdere, hvis abonnement betales af Sønderjysk Skoleforening. I løbet af de sidste fire år fra 1970 til i dag har der været en jæun og stat fremgang år 
for år på tilsammen 200 holdere, en fremgang, som redaktionen selv måske næppe føler sig helt tilfreds med, men som den til gengæld $i$ en tid, hvor mange føler sig nødsaget til at indskrænke ikke strengt nødvendige udgifter, med rette kan føle sig lidt stolt over. Sønderjysk Månedsskrift var i 1973 på i alt 436 sider, og indholdet omfattede såvel historisk som aktuelt stof. I let laselig form er der år for år blevet bragt en fylde af historiske artikler og beretninger i Sønderjysk Månedsskrift, og det må navnlig for historielærere $i$ folkeskolen være en fundgrube til eksemplicificerende eller uddybende materiale i undervisningen. Sønderjysk Månedsskrift bør findes på alle lærerværelser og i alle skolebiblioteker. Som det vil være årsmødets deltagere bekendt, modtog Historisk Samfund for nogle år siden $50.000 \mathrm{kr}$. fra forsikringsselskabet Hafnia til støtte for udgivelsen af Sønderjysk Månedsskrift. Dette beløb er nu opbrugt, og for at kunne opretholde udgivelsen i sit hidtidige omfang har det været nødvendigt at forhøje abonnementprisen til $42 \mathrm{kr}$. årligt, men selv med denne forhøjelse kører tidsskriftet med et betydeligt underskud, som kun delvis dækkes ved støtte fra Dansk Kultursamfund.

Det er $\mathrm{i}$ år 50 år siden, Claus Eskildsen og $\mathrm{H}$. Lausten-Thomsen begyndte at udgive Sønderjysk Månedsskrift, og dette jubilæum vil naturligvis blive benyttet af styrelsen til at søge støtte til den fortsatte udgivelse. En vis indirekte støtte har tidsskriftet $\mathrm{i}$ år allerede fået derved, at $\mathrm{Mu}$ seumsrådet for Sønderjyllands Amt har stillet sin årbog »Nordslesvigske Museer « til rådighed for Sønderjysk Månedsskrifts abonnenter, således at den næunte årbog er indgået som et dobbelthæfte marts-april. Denne ordning skulle også gælde fremover, og den er både i Historisk Samfunds og museernes interesse, idet disse derved når ud til et bredere publikum, som de måske ellers vanskeligt ville kunne komme i kontakt med. Historisk Samfund er museumsrådet og specielt dets formand, amtsborgmester Erik Jessen, taknemmelig for gennemførelsen af denne ordning.

Inden for serien Skrifter, udgivne af Historisk Samfund for Sønderjylland er det nu langt om længe lykkedes at få bind III af Ảbenrå Bys Historie så vidt, at den nu foreligger i korrektur, og efter sommerferien skulle denne med så megen længsel imødesete bog kunne fremsendes til subskribenterne. I denne forbindelse kan nævnes, at Åbenrå byråd i princippet har erklaret sig villig til at medvirke ved udgivelsen af yderligere tre bind, nemlig et bind omfattende tiden efter 1945 og et bind for hvert af de indlemmede sogne Løjt og Ensted. Det er vort håb, at der vil kunne findes dygtige medarbejdere hertil. Arbejdet med bogen om de sønderjyske historikere efter 1864 er i god gænge med arkivar Dorrit Andersen som redaktionssekretær. De mange medarbejdere skal aflevere deres manuskripter senest 15. august $i$ år, og bogen skulle så kunne foreligge færdig $i$ løbet af vinteren. Der foreligger også andre manuskripter, hvis udgivelse overvejes inden for skriftrækken.

I serien Sønderiyske levnedsløb kunne, ikke til jul som håbet, men først et stykke hen $\mathrm{i}$ det nye år udsendes Peter Becks erindringer fra drenge- 
årene på Sundeved. Bogen, der har fået fremragende anmeldelser, er faldet i medlemmernes smag $i$ den grad, at et andet oplag på 500 eksemplarer måtte trykkes for at kunne tilfredsstille efterspørgslen. Der er endnu ikke taget stilling til, om der $\mathrm{i}$ år skal udsendes et nyt bind $\mathrm{i}$ denne serie.

Historisk Samfund har endvidere sammen med Ảbenrå byhistoriske Forening og landsarkivet været impliceret $i$ udgivelsen af Morten Kamphöveners borgerskabsbog for Abenrå. Selve biografierne, der i alt fylder 235 sider, er duplikerede i 300 eksemplarer. I lobet af kort tid følger et registerbind på ca. 125 sider, og de to bind vil derefter kunne købes af interesserede. Redaktør Kamphövener har lagt et kxmpearbejde $i$ udarbejdelsen af de ca. 3.000 biografier af Ảbenrå-borgere, og det er glædeligt, at resultatet af dette store arbejde nu $i$ lobet af ganske kort tid kan blive kendt af et større publikum. For de åbenråske slægtsforskere vil værket være en guldgrube.

Som det vil erfares ved regnskabsaflæggelsen, henstår der et betydeligt beløb til udgivelse af bind II og IV af Sønderiylland. Historisk Billedbog. Men udgifterne ved udgivelsen er så store, at vi indtil nu har ment at måtte stille os lidt afventende. De penge, der kommer ind ved salget af bd. I og III, skal bl. a. være med til at sikre udgivelsen af bd. II og IV, der henholdsvis skulle omfatte 1864-1920 og Sydslesvig efter 1920. Når vi har så betydelige beløb stående på bankbog, er det altså ikke udtryk for rigdom, men mere et udtryk for, at vi ikke har tilstrækkelige midler til den fortsatte billedbogsudgivelse. Hertil kan føjes, at styrelsen $i$ formiddags har besluttet, at udgivelsen af bd. IV (Sydslesvig 1920-) skal påbegyndes nu. Troels Fink er forfatter af teksten til dette bind. Udsendelsen af bind II er derefter udskudt indtil videre.

For et par år siden modtog vi fra Dronning Ingrids Fond 25.000. til en konkret forskningsopgave. Med dronningens tilladelse blev der derefter udskrevet en prisopgave om emner knyttet til Gråsten. Ved afleveringsfristens udløb den 1. september sidste år var der indkommet een besvarelse, som imidlertid af det nedsatte bedømmelsesudvalg bestånde af professorerne Troels Fink og Olaf Olsen og studielektor H. V. Gregersen ikke fandtes værdig til uddeling af en pris. Det er meget beklageligt, at udskrivningen af denne prisopgave førte til et så negativt resultat. Vi vil nu i samarbejde med nogle historieprofessorer ved universiteterne søge at finde frem til formulering af en opgave, som unge historikere kunne tankes at have lyst til at gå $i$ lag med.

Inden for Historiske Samlinger har vi bl. a. isæer på grund af flytning og tilbageflytning måttet føre en ret stille tilværelse. Samlingerne har nu fået gode lokaler, dels et billedarkiv, hvor der nok vil være plads til den første kvarte million billeder og negativer, dels et båndarkiv og et afspilningsrum. Endelig er det meningen, at Historiske Samlinger også skal kunne udnytte det fotografiske atelier, når det inden alt for længe er færdig monteret. Der er arbejdsrum til et par medarbejdere, og her opbevares også det stadig voksende kartotek over de registrerede billeder. Fru Vibeke Gribsvad 
har som tidligere år også i år været beskæftiget med ordning og registrering af billederne, hvoraf der $i$ beretningsåret 1973/74 er afleveret $i$ alt 2972 stk., noget mindre end sidste år, men dog en anselig mængde. Og det er værd at bemærke, at der er meget værdifulde gaver fra arvingerne efter Ingeborg Refslund Thomsen og efter Jep Fink. I Tønder amt er fotograferingen af gamle bygninger fortsat under ledelse af tidligere forstelærer $W$. Leick. Der mangler kun meget lidt $i$, at arbejdet $i$ Tønder amt er afsluttet, og det vil derefter være naturligt at fortsætte fotograferingen i samarbejde med amatørfotografer $i$ andre egne af landsdelen. Historiske Samlinger har også været med til at levere fotografierne til den lille udstilling i landsarkivets faste montrer, som præsenteredes ved landsarkivets indvielse. Båndsamlingerne har fået en meget betydelig tilvækst, idet fru Karl Clausen sammen med Danmarks Radio har overladt Historiske Samlinger flere hundrede bånd med Karl Clausens optagelser. De er endnu ikke endeligt registreret, men det er vort håb, at vi kan få kvalificeret medhjzelp hertil.

Kaster vi blikket mod møde- og udflugtsvirksombeden, er det værd at bemærke, at foreningen for første gang har gennemført en weekendudflugt med overnatning, endda med en så overvældende tilslutning, at turen, der var tilrettelagt af nxstformanden, Chr. Stenz og museumsinspektør, dr. phil. Sig. Schoubye, måtte dubleres. De to ture, der fandt sted henholdsvis den 8.-9. september og 6.-7. oktober var dog ikke helt identiske. Lübeck, Ahrensburg og Segeberg var fæelles mål, men medens det første hold så det ny istandsatte Schierensee og den gamle Gottorper-residens Eutin, beså det andet hold et interessant kakkelovnsmuseum i Büdelsdorf ved Rensborg, den vendisk prægede kirke i Bosau og museet og slottet i Plön, som jo kan fremkalde minder af både den ene og den anden art. I alt var der 133 personer med på de to overnatningsudflugter.

I amtskredsene har der været god tilslutning til de forskellige arrangementer. Tønder amt stod sidste sommer for arrangementet af den bistoriske søndag, som fandt sted den 5. august i og omkring Løgumkloster. Der var ca. 120 betalende deltagere, idet man, som amtsformanden meddeler, ikke kunne tage entre alle vegne. Der har nok været ca. 250 deltagere i alt.

Med undtagelse af Sønderborg har alle amtskredsene afholdt sommerudflugter eller egnsvandringer - Haderslev-kredsen endda to. I alt har der af amtskredsene varet arrangeret 5 udflugter med op imod 400 deltagere, tre aftenvandringer med 150 deltagere og ikke færre end 12 foredragsmøder med et tilhørertal på op imod 700. I denne forbindelse skal næevnes, at pastor Paul Tappe, der er medlem af ledelsen for Sydslesvig-kredsen, i Læk har arrangeret en udstilling af lokale billeder fra tiden for 1914. Denne udstilling besøgtes af $i$ alt 1025 - et meget talende vidnesbyrd om, at hvor der er initiativ og virkelyst, belonnes anstrengelserne. Det kirkehistoriske udvalg, som før var meget aktivt, har ligget lidt stille det sidste par år, men dets formand pastor Urban Schrøder har medvirket ved tre kirkebesøg. Tilslutningen til disse arrangementer viser klart, at medlemmer og andre historisk interesserede værdsætter denne side af foreningens virksom- 
hed, som utvivlsomt også er med til at stabilisere og aktivere medlemskredsen.

Og så vil jeg, som jeg plejer, gerne slutte med at sige tak for den støtte, foreningen nyder fra fonds, stat og kommuner. Uden denne økonomiske hjelp ville foreningens forskellige tiltag slet ikke kunne gennemføres. Jeg vil også bringe en tak til medarbejderne $i$ styrelsen, $i$ amtsudvalgene, på sekretariatet og sidst men ikke mindst til de mange tillidsmænd rundt omkring i sognene, hvis tid og arbejdskraft vi på den ene eller anden måde har lagt beslag på. Uden forstålse og interesse $i$ vide kredse for værdien af det folkelige historiske arbejde kunne Historisk Samfunds mangesidede virksomhed slet ikke trives.

Efter formandens beretning gav dirigenten ordet til kassereren, bankdirektør $H$. Lildholdt, der aflagde regnskabet (jvf. omstående), og såvel formandens beretning som regnskabet blev godkendt af årsmødet.

Under punkt 3: valg meddelte dirigenten, at Werner Christiansen, Knud Fanø, Johan Hvidtfeldt og Tage Madsen var på valg. Sidstnævnte, som var foreningens sekretær, ønskede ikke genvalg. I stedet for ham valgtes skoleinspektør Knud Kristensen, Stubbæk, og endvidere indvalgtes sparekassedirektør H. P. Jensen, Agerskov, som nyt medlem. Werner Christiansen, Knud Fanø og Johan Hvidtfeldt genvalgtes.

Under eventuelt redegjorde formanden for planerne vedr. næste årsmøde, Historisk Søndag og Historisk Samfunds egnsvandring og efterlyste forslag fra medlemmerne m.h.t. målet for egnsvandringen. $\mathrm{Da}$ ingen andre ønskede ordet, sluttede dirigenten årsmødet.

Efter kaffen besøgte deltagerne landsarkivet, hvor der var lejlighed til under ledelse af arkivarerne Dorrit Andersen og Jorgen Witte samt landsarkivar Peter Kr. Iversen at bese nybygningen, herunder Historisk Samfunds og Historiske Samlingers nyindrettede lokaler. 


\section{Regnskab for året I. april 1973 til 3 I. marts 1974 \\ Indtegter: \\ Udgifter:}

Beholdning pr. 1.4.73 ... 147.398,62

Medlemsbidrag $\ldots \ldots \ldots .56 .319,90$

Salg af skrifter ....... 27.364,15

Sønderjysk Manedsskrift:

abonnements, annoncer . $85.388,70$

tilskud .......... 21.000,00

Andre tilskud ........ 109.097,40

Renter ........... 16.303,02

Moms $\ldots \ldots \ldots \ldots \ldots \quad 3.241,53$

Kr. $466.113,32$
Sønderjyske Årbøger .... 59.779,35

Skrifter ............. 28.398,64

Sdrj. Månedsskrift ..... $82.053,61$

Kontorhold ......... 5.630,10

Lønninger $\quad \ldots \ldots \ldots \ldots . \quad 36.072,87$

Møder o.1. . ........ $3.461,45$

Repræsentation $\ldots \ldots \ldots . \quad 1.721,85$

Amtskredsene ....... $4.350,00$

Kontingent SLF ...... 2.255,20

Forsikringer o.1. ...... 1.449,20

Porto o.l. .......... 1.247,48

Diverse ........... $\quad 765,84$

Egnsvandring $\ldots \ldots \ldots \ldots \quad 1.965,63$

Beholdning pr.31.3.74 .. 236.962,10

Kr. $466.113,32$

\section{Status pr. I. april r 974}

Aktiver:

Beholdning $\ldots \ldots \ldots \ldots 236.962,10$

Udestående for salg .... 2.395,00

Kr. $239.357,10$
Passiver:

Ingrid Fondet for Sdj. . $\quad 31.797,25$ Henlagt til:

Ābenrå Bys Historie III 27.000,00

Senderjylland. Historisk

Billedbog II og IV .... 119.187,54

Sønderjyske Historikere 25.000,00

Egnsvandringsfond ..... 4.239,29

Skyldig moms ....... 4.640,00

At overføre til næste år .. 27.493,02

Kr. 239.357,10

Ảbenrå, den 24. april 1974 .

H. Lildboldt

Foranstående regnskab er revideret med bilagene, giro- og bankkonti og er fundet i orden.

Ảbenrå, den 4. maj 1974.
Sv. $L y c k$
C. O. Henningsen 


\section{Tillæg til medlemsfortegnelsen}

Efterfølgende supplement til den i årene 1955 til 1973 offentliggjorte medlemsfortegnelse for Historisk Samfund for Sønderjylland medtager som i de foregående år $\mathrm{i}$ afgangslisten kun de afdøde medlemmer, hvis død er kommet til vort kendskab, medens tilgangslisten omfatter alle nye medlemmer $\mathrm{i}$ alfabetisk rækkefølge.

Pr. 1. april 1974 udgør medlemstallet 2822, der fordeler sig på Sønderjylland og det ovrige land samt udlandet som følger:

Haderslev by ............. 190

Haderslev amt ............. 344

Sønderborg by ............. 91

Sønderborg amt ............ 189

Tønder by ............... 144

Tønder amt ............. 276
Åbenrå by $\ldots \ldots \ldots \ldots \ldots \ldots 259$

Åbenrå amt ................ 284

Sydslesvig $\ldots \ldots \ldots \ldots \ldots \ldots 183$

Storkøbenhavn .......... 279

Øvrige Danmark ......... 546

Udlandet .............. 37

\section{Afgang ved død}

Beck, Christian, rentier, Ābenrå

Billund, Marie, fru, Ảbenrå

Eskildsen, Hans, overlærer, Sæd

Fink, Jep, arkitekt, Ảbenrå

Hansen, H. Chr., gæstgiver, Ảbenrå

Heitmann, Herm., overlærer,

Lyksborg

Hylsebeck, pens. overtoldassistent, Haderslev

Iversen, Georg, Gelting
Jensen, Henry V., husejer, Seem

Jorgensen, Hans, kommunesekretær, Vester Sottrup

Jørgensen, Peter, graver, Haderslev

Nissen, Nis, fhv, arkivassistent Genner

Rohleder, Harald, provst, Sønderborg

Schack, Erik, generalkonsul, greve, Emborg

Skov, Sophie, frk., Sommersted
Andersen, Børge, lærer, Ābenrå

Andresen, Johan Chr., gårdejer, Perbel

Asmussen, Ingrid, ekspeditrice, Ābenrå

Asmussen, Uwe, bankassistent, Rødekro

Auken, Eva, stud. mag., Århus

Becker, Ulf M., stud. mag., Hvidovre

Boger, Sonja, fru, Ảbenrå

Borg, Christa, lærer, Husby

Borst, Hans, bagermester, Vojens
Tilgangsliste

Boysen, Carsten, gårdejer, Risum

Brummer, Birthe, sygehjælper, Fjelstrup

Bøgen, Claus, overlærer, Haderslev

Christensen, Hans J., gårdejer, Burkal

Christiansen, Finn Riefler, soc., Alborg

Clausen, Bothilde, damefrisør, Augustenborg

Clausen, Jørgen, landmand, Asserballeskov

Dahl, Leif, lærer, Harreslev 
Danmarks Lærerhøjskole, København Davidsen, Iver, murermester, Vojens Ditlev, Ella, larer, Nordborg Dyvig, Peter, kontorchef, Skodsborg Ehlers, John, stud. mag., Århus Gad, Inger, fru, Hejsel

Gregersen, Frands, turistchef, Ảbenrå

Grønvold, Erik R., Virum

Gaardsvig, Henning, stud. mag., Abyhøj

Hamer, Berthold, Glücksborg

Hansen, Lilly, sundhedsplejerske, Slesvig

Hansen, Markus, gårdejer, Lendemark

Hansen, Povl Verner, skoleleder, Store Vi

Hansen, Svend Aage Nordvang, Rodding

Hansen, Søren Frei, stud. mag., Arhus Haugaard, Henning, lærer, Kolding Haunse, Sigurd, kontorchef, cand. polit., Gentofte

Helin, Kirsten, stud. mag., Arhus

Henschel, Ronny, arkitekt, Rinkenæs

Herbers, Christa C., lærerstuderende, Haderslev

Herrgut, Anita, fru, Flensborg

Hohwü-Christensen, Jens, urmager, Gråsten

Holck, Niels, seminarierektor, Haderslev

Hoop, Horst, lærer, Vollerwich

Iversen, Wilhelm, Satrup

Jacobsen, Jørgen, revalideringskonsulent, Ulkebøl

Jensen, Agnes Skrydstrup, fru, Øster-Højst

Jespersen, N., amtsvandinspektør, Åbenrå

Jespersen, Per, lærer, Øster-Højst

Jessen, Harald, pensionist, Horsens

Jessen, Jørgen, seminarielektor, Tjørring

Johannsen, Matthias, Varde

Johnsen, Inge, landbrugsmedhjælper,

Skxrbxk

Jornil, Ib, ingenior, Havnbjerg Syd

Jørgensen, Christian, Lyngby

Keck, Otto, salgschef, Haderslev
Kiil, Bodil, sundhedsplejerske, Roskilde

Kirkeby, Henning, direktør, Alborg

Kjar, Eyvin Teisner, ekspeditionsleder, Ulkebøl

Knudsen, Gunnar, postbud, Hellevad

Kock, Bjarne Chr., bankdirektør, Tønder

Krause, Max, major, Stenderup

Kristensen, Erik Vinther, Bagsvard

Kristensen, Jutta, lærer, Arrild

Lampe, Carl Erik, røntgenoverlæge, Ulkebøl

Land, Sigurd, afdelingschef, Augustenborg

Larsen, Oskar, aut. el-installatør, Over Jerstal

Lauenborg, Karen, ekspeditrice, Haderslev

Lauridsen, Eva, lærer, Bylderup-Bov

Lawaetz, Th., fotohandler, Abenrå

Lempert, Gerhard, amtssekretær, Tonning

Lerbak, Jytte Dyrup, bibliotekar, Ảbenrå

Lindhard, Kirsten, stud. mag., København

Loff, Ottomar, direktør, cand. merc., Sonderborg

Lorenzen, Emil, Flensborg

Madsen, Hakon Bennike, studielektor, Fruens Bøge

Madsen, Lars Aaberg, stud. mag., Brabrand

Matzen, Carl, teglværksejer, Egernsund

Maybom, Aage, postmester, Gråsten

Mogensen, Leif, bogtrykker, Ả benrå

Mogensen, Mogens Stensbæk, stud. mag., Århus

Morthorst, Erik, gårdejer, Øster-Løgum

Moseholt, P. B., slotsgartner, Gråsten

Møller, Chr. Hansen, gårdejer, Brobølgảrd

Nielsen, Claus P. Wolff, Gammelgab

Nielsen, Erik Manthei, tekniker, Pøl

Nielsen, Jens Norman, adjunkt, Flensborg

Nielsen, Lizette, stud. mag., Århus 
Nielsen, Niels, landmand, Roost

Nielsen, Niels L. L., stud. mag., Ārhus

Nielsen, Torben Steiner, adjunkt,

Kolding

Nissen, Johan, Vester Vedsted

Nordiska Bokhandeln, Stockholm

Nørgaard, Carl, overlærer,

Kobenhavn

Nørgaard, G. R., soldat, Schackenborg

Oksbjerg, Erik, gårdejer, Stepping

Paulsen, Marcus M., Oksbel

Pedersen, Aksel Kofoed, invalidepensionist, Varnæes

Pedersen, Astrid Schjødt, lærer, Tonning

Peters, Kurt F., adjunkt, cand. polyt., Odense

Petersen, Dorthea, fru, Øbening

Petersen, Ernst, stud. mag., Søborg

Petersen, Math., gårdejer, Hjordkær

Petersen, Paul, gartner, Uge

Petersen, Ulla Holm, stud. mag., Abyhoj

Philipsen, Johan, gårdejer, Avnbellund

Pinholt, Erik, lærer, Haderslev

Posselt, Christine, sygeplejerske, Tonder

Posselt, Helge, gårdejer, Møgeltønder

Poulsen, Svend, førstelarer, Jyderup

Præst, Hans, viceskoleinspektør, Havnbjerg

Pørksen, Johannes, afdelingsleder, Sønderborg

Rasmussen, Geert, musiker, Høruphav

Rose, Niels, lærer, Rødekro

Scharff, A., professor dr., Kiel

Schmidt, Agnete, lage, Âbenrå

Schmidt, Børge, lærer, Tønder

Schmidt, Hans, købmand, Ảbenrå
Schoemmel, Roy, lærer, Haderslev

Schultz, Knud, landmand, Bæk

Seedorff-Rasmussen, N. H., sognepræst, Ullerup

Sibbesen, Peter C., toldassistent, Tåstrup

Skjoldager, Gitte, stud. jur., Løgumkloster

Skov, Sophie, Sommersted

Skovrup, Marie, sygeplejerske, Sønderhav

Smidt, Alexander, Søbxkled

Sohl, Egon, salgsdirektør, Hjørring

Spoorendonk, Anke, stud. mag., Kastrup

Stabenow, Georg, ingenior, East Stroudburg, USA

Svennesen, Anne E., Barsmark

Søllerød Kommunebibliotek, Nerum

Sørensen, N. Møller, sognepræst, Kliplev

'Tange, Agnes, larer, Logumkloster

Thaysen, Hilma, kontorassistent, Nordborg

Thiesgaard, Chr. L., boghandler, Gråsten

Thomsen, Emmy, husmoder, Lindskov mølle

Thomsen, Jens Jørn, stud. mag., Århus

Thordsen, Jørgen, gårdejer, Pindesholm

Thygesen, Engdahl, dr., Hamburg

Ullerup sogns hjemstavnsforening, Ullerup

Valentin, Jørgen, gårdejer, Svenstrup

Westergaard, Ole, trafikkontrollør, Randers

Vogtherr, Thomas, stud. phil., Kiel

Wolters, Jens, landinspektør, Thisted Aabenraa Museum, Ābenrå 
